\title{
PHYTOEXTRACTION OF CADMIUM AND LEAD FROM A CONTAMINATED SOIL USING EUCAL YPTUS SEEDLINGS
}
S. W. K. Al-Salmany
I. A. Ibrahim
Researcher
Prof.

Department of Forest Sciences, College of Agriculture and Forestry, University of Mosul, Iraq suhaib.waleed88@gmail.com

eng_ibrahim1958@yahoo.com

\section{ABSTRACT}

This study aims to estimate critical concentrations of cadmium $(\mathrm{Cd})$ and lead $(\mathrm{Pb})$ in the soil which negatively affect growth of Eucalyptus camaldulensis Dehnh. seedlings, and to estimate some phytoextraction parameters for heavy metals (HM) from the soil to evaluate efficiency of seedlings in their potential use in phytotechnology to improve the environment with phytoremediation. Eucalyptus seedlings were treated with $\mathrm{Cd}$ concentrations $0,25,55,85$, and $110 \mathrm{mg} \mathrm{kg}{ }^{-1}$ dry soil as $\mathrm{CdCl}_{2}$, and $\mathrm{Pb}$ concentrations $\mathbf{0 , 1 2 5}, \mathbf{2 5 0}, \mathbf{4 5 0}$, and $550 \mathrm{mg} \mathrm{kg}^{-1}$ dry soil as $\mathbf{P b C l}_{2}$, and the experiment was designed using the completely randomized design (CRD) as a two-factor factorial experiments and the data were analyzed using SAS system. Results showed that the highest percentage decrease in dry weight of stems, leaves and roots were $55,68.6$, and $67.2 \%$, respectively, at the interaction $(110 \mathrm{Cd}$ and $550 \mathrm{~Pb})$ $\mathrm{mg} \mathrm{kg}^{-1}$ dry soil compared with control, and Cd concentrations in stems, leaves and roots ranged between (0.375-372.167), (0.417-128.167) and (0.583-162.083) $\mathrm{mg} \mathrm{kg}^{-1}$, respectively and $\mathrm{Pb}$ concentrations in stems, leaves and roots ranged between $(9.583-62.375),(10.042-20.417)$ and $(2.875-$ 73.500) $\mathrm{mg} \mathrm{kg}^{-1}$. It was found that values of translocation factor (TF), biological accumulation coefficient (BAC), bioconcentration factor (BCF) and concentration index (CI) for Cd ranged between (0.611-4.239), (1.333-28.790), (0.383- 16.840) and (1-490.812) respectively, and values of TF, BAC, BCF, and $\mathrm{CI}$ of $\mathrm{Pb}$ ranged between $(0.275-5.702),(0.769-4.246),(0.295-7.539)$ and (1-3.833) respectively, and tolerance index (TI) values ranged between (0.370-1). We concluded that Eucalyptus seedlings are suitable for phytoextraction applications within phytoremediation processes of soils contaminated with $\mathrm{Cd}$ and $\mathrm{Pb}$.

Keywords: Phytoremediation, Biomass, Accumulation, Environmental Pollution, Heavy Metals.

السلماني وابراهيم

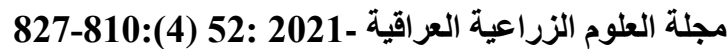

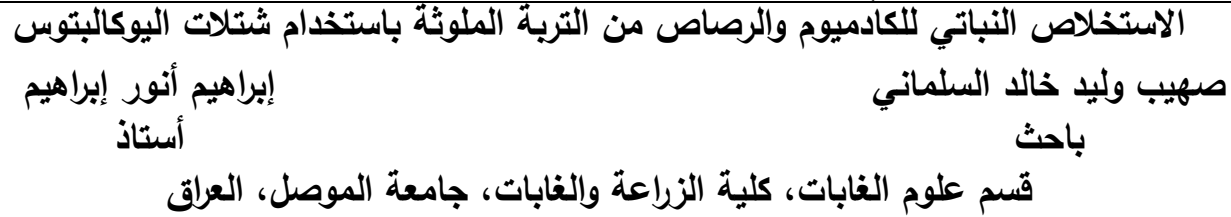

تهاف هذه الدراسة الى تقلير التركيزات الحرجة للكادميوم والرصاص في التربة والتي تؤئر سلباً في نمو شتلات اليوكالبتوس (Eucalyptus) camaldulensis Dehnh.) الثتلات في إمكانية استخدامها في التقيات النباتية (Phytotechnology) تلتصين البيئة بتقبة المعالجة التباتية (Phytoremediation).

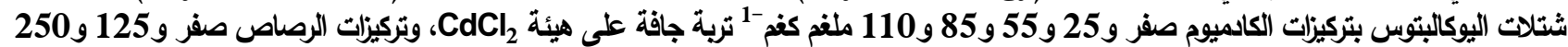

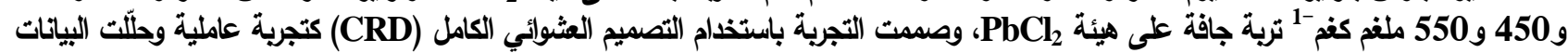

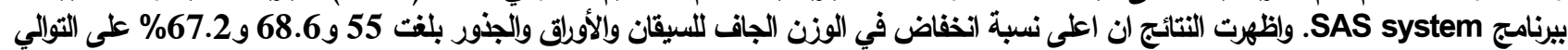

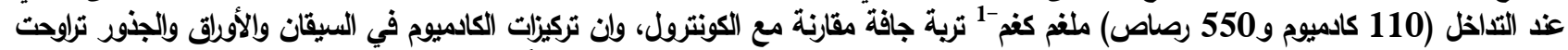

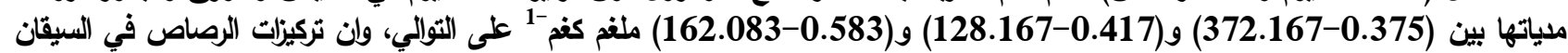

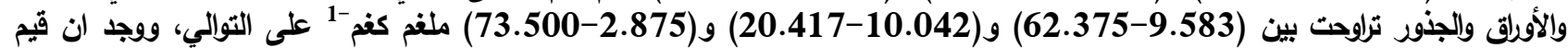

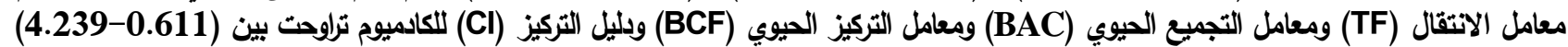

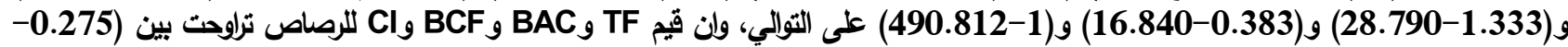

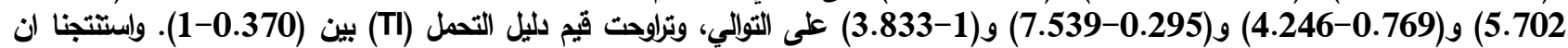

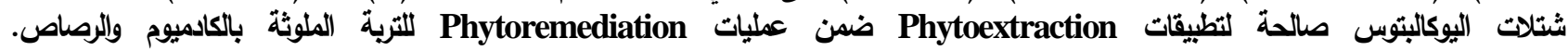
الكلمات المفتاحية: المعالجة النباتية، الكتلة الحيوية، التراكم، التلوث البيئي، المعادن الثقيلة. 


\section{INTRODUCTION}

Environmental pollution is the presence in the environment of any pollutant substance in the environment in quantities that directly or indirectly, alone, or by the interaction with others, harms public health or causes the ecosystems to disrupt or stop them from performing their normal role in the ecosystem, and the soil is contaminated by containing a substance or substances in high concentrations that threaten human, animal or plant health or disturb the natural standards of surface and groundwater. Heavy metals are considered the most dangerous pollutants to the environment of living organisms, resulting from the remnants of technologies created to serve humanity such as mining, factories, electric power stations, agricultural pesticides, hospitals, sewage waste, human consumption waste, means of transportation, and the mineral origin of the earth's crust $(5,57)$. They affect proteins and enzymes, some of which are genotoxic and carcinogenic substances that affect the chemical composition of DNA, as well as inhibit the process of genetic reproduction. Plants possess defenses against heavy metals such as phytochelatins, which can bind the heavy metals to be physiologically inactive or by depositing them in special sites in plant cells $(5,32)$. It is worth noting that some the heavy metals play a fundamental role in metabolism, while others are trace elements and toxic elements that do not have a biological role, as in $\mathrm{Cd}$ and $\mathrm{Pb}$, as they move to humans through the food chain, leaving him with serious diseases such as the programmed killing of his cells, which lead to death $(19,36,48)$. Cadmium (Cd) is one of the heavy metals most dangerous to the environment, which is characterized by high toxicity even in its low concentrations as well as its rapid transfer to cellular tissues to settle in it, causing morphological, physiological and biochemical changes as it works to reduce the levels of growth, photosynthesis and cellular processes of the plant, and $\mathrm{Cd}$ in its critical concentrations leads to cell damage and plant death $(24,37)$. As for lead $(\mathrm{Pb})$, which is more prevalent in the environment than other highly toxic heavy metals (23), when it is stabilized in plant tissues, it reduces vegetative growth due to its effect on the structural and physiological properties, as it reduces photosynthesis, impedes the action of stomata in leaves and reduces enzymatic functions in plant tissues, its high concentrations cause cellular stress that leads to plant death $(6$, 17). In order to get rid of heavy metals, plants and micro-organisms were used to remove them from the environment, as they are the most preserving the environment and living organisms and for the economic and social benefits they generate, phytoremediation has become known as a modern innovation technology that is reflected in the absorption of heavy metals from soil, water and air are then transported and concentrated in their cellular tissues, and phytoextraction, which involves the use of plants to absorb excessively accumulated heavy metals from the surrounding environment, transport and concentrate them in their biomass $(3,5,16)$, it is the most common in phytoremediation operations, as it is a very appropriate technique in terms of material cost and as it improves the quality of soil and water satisfactorily within an appropriate time limit, good for extraction, by analyzing and reserving the hazardous contents in the media in which the plants grow, as well as making plans a long-term strategy for making genetic modifications on good plants in the phytoextraction process in order to increase their relatively rapid growth rate as well as to obtain high-yielding biomass and to make them adaptable to different environmental conditions and to demonstrate the characteristics of the different genetic characteristics of the species (45). The accumulation of toxic heavy metals in agricultural areas leads to great concerns about food safety and its impact on the productivity of food crops and thus its negative impact on the food security of human societies (50), and there are types of plants called hyperaccumulators that can absorb and transport large quantities of the heavy metals, and storage in their cellular tissues, and despite their high storage capacity, in cases of soil contamination with large quantities of the heavy metals, plants do not fully perform their function due to their small biomass compared to the size of pollution, so it is preferable to choose plant species with large and fast-growing biomass, that can absorb greater amounts of inorganic pollutants in general and heavy metals in particular $(10,40)$, therefore, recent studies have encouraged the treatment of polluted soils with heavy metals by selecting forest trees that are distinguished by their lack of contribution to the food chain, and high yield of biomass, and among the forests that are 
characterized by these characteristics are Eucalyptus, Willow, Poplar and Castor (2, 21). Where a study was conducted on Poplar hybrids in Serbia for Populus deltoides for clone (B-81) and Populus $\times$ euramericana for clone (Pannonia) on the possibility of phytoremediation of soils contaminated with $\mathrm{Cd}$ using, which were treated with a concentration of $\mathrm{Cd} 8.14 \mathrm{mg} \mathrm{kg}^{-1}$ dry soil, the study showed that the decrease in biomass production was significantly greater in Pannonia than in B-81 (42). And in a study conducted by Lamb et al. (29) in Australia to investigate the effect of $\mathrm{Cu}, \mathrm{Zn}, \mathrm{Cd}$ and $\mathrm{Pb}$ on the root elongation for four types of native trees and other natural herbs which treated with concentrations of $\mathrm{Cd}$ and $\mathrm{Pb} 0,0.1,1,10,100,500$ and $1000 \mu \mathrm{M}$, as well as with concentrations of $\mathrm{Cu}$ and $\mathrm{Zn} 0,0.1$, $1,10,100,1000$ and $2000 \mu \mathrm{M}$, and the results showed that high concentrations of heavy metals reduced the growth rate to $50 \%$, as $\mathrm{Cd}$ concentrations of root ranged from $27 \mu \mathrm{M}$ in Lactuca sativa to $940 \mu \mathrm{M}$ in Acacia species, and $\mathrm{Pb}$ concentrations ranged between $180 \mu \mathrm{M}$ in $\mathrm{L}$. sativa to $1000 \mu \mathrm{M}$ in Acacia species, and Cd was found to be more toxic than $\mathrm{Pb}$. As for the study by Ashraf et al. (8) showed an increase in stalk Cd concentrations from (4.20-9.70) and (3.308.50) $\mathrm{mg} \mathrm{kg}^{-1}$ in the seedlings of Conocarpus erectus and Eucalyptus camaldulensis, respectively, when the $\mathrm{Cd}$ concentration increased from 5 to $5.15 \mathrm{mg} \mathrm{kg}^{-1}$, and Cd concentrations in the roots increased from (8.20-24) and from (6.10-17.40) $\mathrm{mg} \mathrm{kg}^{-1}$ in seedlings of C. erectus and E. camaldulensis, respectively, with increasing the soil $\mathrm{Cd}$ concentration from (5-5.15) $\mathrm{mg} \mathrm{kg}^{-1}$, while the BCF values were greater than one for the two species and for all Cd coefficients, and the BCF values for the two species were higher in $C$. erectus seedlings than $E$. camaldulensis, and the TF values were less than one for both species and for all Cd levels, it was higher in E. camaldulensis than C. erectus. Also studied Alkhatib et al. (4) the effects of $\mathrm{Pb}$ on growth rate, physiological and biochemical characteristics in Leucaena leucocephala seedlings, as the results showed that the effect of $\mathrm{Pb}$ led to a decrease in growth rate of seedlings treated with concentrations 300,500 and $700 \mu \mathrm{M}$, whereas $\mathrm{Pb}$ concentrations of 25 , 50 and $100 \mu \mathrm{M}$ did not show any toxic effect on seedlings.

\section{MATERIALS AND METHODS}

Field work: On March 14, 2019, ten-monthold were transferred Eucalyptus camaldulensis Dehnh. seedlings from central nursery in the city of Mosul to the wooden shelter in nursery for College of Agriculture and Forestry at University of Mosul at a longitude $\left(43^{\circ} 09^{\prime}\right)$ north and latitude $\left(36^{\circ} 19^{\prime}\right)$ east, and seedlings were planted in pots its internal diameter and depth is $28 \mathrm{~cm}$, then the soil was added to it to bring its dry weight to $13.125 \mathrm{~kg}$ pot $^{-1}$ approximately, and seedlings were distributed randomly, and after two weeks of transferring the seedlings to the pots, they were treated with concentrations of $\mathrm{Cd}$ and $\mathrm{Pb}$, and the service operations continued, such as watering and weeding, until November 21, 2019, three seedlings from each treatment, randomly selected, and then field measurements were made for them after extracting them from the pots, cleaning them from the soil, separating roots, stems and leaves separately, taking soil samples for each seedling from the area near the roots, and then the plant samples and soil samples were placed in cardboard bags with the number of treatment, refined, and sample type recorded, and (Picture 1) showed the seedlings in the wooden shelter at the start and end of the experiment.

Soil analyzes: The analyzes of the soil sample taken at the start of study (before adding heavy metals) (Table 1), were conducted as indicated by El-Mahrouk et al. (17), which it included measuring the electrical conductivity (EC) according to the ratio (1 soil: 5 distilled water) and was measured using a device EC meter, and the $\mathrm{pH}$ was measured using a $\mathrm{pH}$ meter and according to the ratio (1 soil: 1 distilled water), and the soil texture was estimated using hydrometer method, and concentrations of $\mathrm{Pb}$ and $\mathrm{Cd}$ in the soil were estimated at the start of study according to Elmer (18), as well as when removing seedlings from pots (at the end of the experiment).

Measuring dry weight of shoot and root: Stems, leaves and roots were dried at a temperature of $65^{\circ} \mathrm{C}$ for about three days until the stability of the weight, and dry weights were recorded immediately after they were removed from electric oven using a sensitivity balance of (1) $\mathrm{mg}$. 


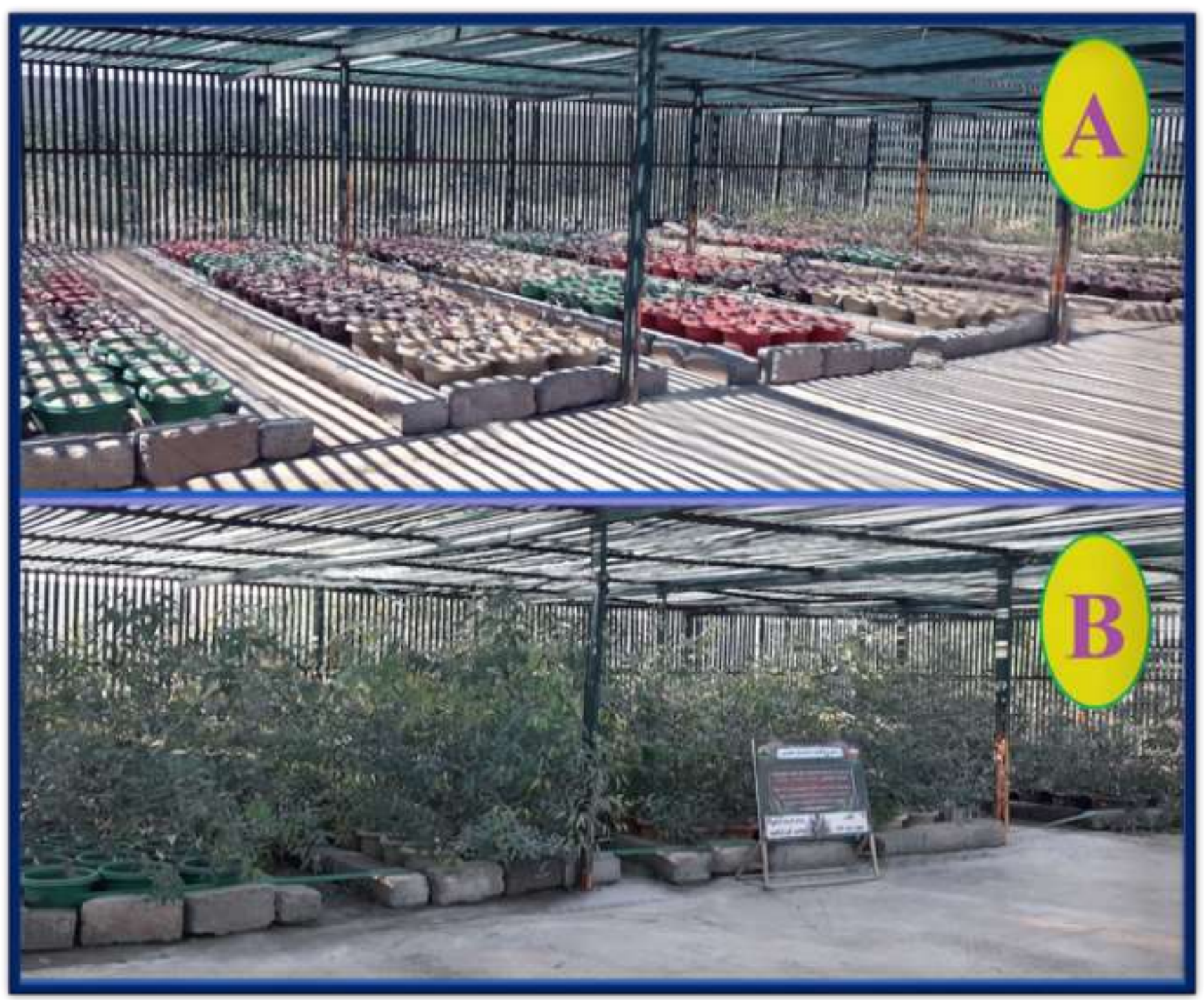

Picture 1. The seedlings at the start of the experiment (A), and at the end of the experiment (B).

Table 1. Soil properties before treatment.

\begin{tabular}{|cc|}
\hline Parameter & Value with unit \\
\hline pH & 7.2 \\
EC & $1.876 \mathrm{dS} \mathrm{m}^{-1}$ \\
$\mathrm{Cd}$ & $0.295 \mathrm{mg} \mathrm{kg}^{-1}$ \\
Pb & $18.750 \mathrm{mg} \mathrm{kg}^{-1}$ \\
Sand & $42.55 \%$ \\
Silt & $21.2 \%$ \\
Clay & $36.25 \%$ \\
Texture & Silty clay \\
\hline
\end{tabular}

Determination of $\mathbf{C d}$ and $\mathrm{Pb}$ concentrations in plant parts: The wet digestion method was used to prepare plant samples (roots, stems and leaves) and according to the method reported by Elmer (18), the dried plant samples were ground separately and $2 \mathrm{~g}$ were taken from each sample and placed in an conical flask, then $10 \mathrm{ml}$ of concentrated nitric acid (HNO3) were added to it, and the samples were left until the next day and then heated on an electric heater until the red fumes from nitrogen dioxide $\left(\mathrm{NO}_{2}\right)$ stopped and the samples were left to cool down, and then (24) $\mathrm{ml}$ of perchloric acid $\left(\mathrm{HClO}_{4}\right)$ were added to them its concentration is $70 \%$, and the samples were heated again until the end of the white vapors resulting from the perchloric acid, noting that a small volume of the sample remained bright as a result of the digestion process, then the samples were left to cool down and then transferred to a $50 \mathrm{ml}$ beaker and the volume was supplemented with distilled water to the mark became the final volume of the plant samples $50 \mathrm{ml}$, then the samples were filtered using filter paper, and then the $\mathrm{Cd}$ and $\mathrm{Pb}$ concentrations of the dried plant samples were estimated by flame method, using an atomic absorption spectrophotometer, SHIMADZU AA7000, Japanese origin, in the Environment 
and Water Research Department of the former Ministry of Science and Technology in Baghdad.

Estimation of translocation factor (TF): It was calculated as reported by Rasheed et al. (49) according to the equation ( $\mathrm{TF}=\mathrm{HM}_{\mathrm{S}} /$ $\mathrm{HM}_{\mathrm{R}}$ ), as $\mathrm{HM}_{\mathrm{S}}=$ concentration of heavy metals in the shoot, and $\mathrm{HM}_{\mathrm{R}}=$ concentration of heavy metals in the root.

Estimation of biological accumulation coefficient (BAC): It was calculated as reported by Chandra and Hoduck (11) and according to the equation $\left(\mathrm{BAC}=\mathrm{HM}_{\text {Shoot }} / \mathrm{HM}_{\text {Soil }}\right)$, as $\mathrm{HM}_{\text {Shoot }}=$ concentration of heavy metals in stem and leaves, and $\mathrm{HM}_{\text {Soil }}=$ concentration of heavy metals in soil.

Estimation of bioconcentration factor (BCF): It was calculated as reported by Chandra and Hoduck (11) and according to the equation (BCF $\left.=\mathrm{HM}_{\text {Root }} / \mathrm{HM}_{\text {Soil }}\right)$, as $\mathrm{HM}_{\text {Root }}=$ concentration of heavy metals in the root, and $\mathrm{HM}_{\text {Soil }}=$ concentration of heavy metals in the soil.

Estimation of concentration index (CI): The calculation was done as reported by Chandra and Hoduck (11) and according to the equation $\left(\mathrm{CI}=\mathrm{HM}_{\text {treated plant }} / \mathrm{HM}_{\text {normal plant }}\right)$, as $\mathrm{HM}_{\text {treated plant }}$ $=$ heavy metals concentration in the treated plant, $\mathrm{HM}_{\text {normal }}$ plant = heavy metals concentration in the control plant.

Estimation of tolerance index (TI): Calculated according to Xu et al. (58) and as in the equation $\left(\mathrm{TI}=\mathrm{DW}_{\mathrm{HM}} / \mathrm{DW}_{\text {control }}\right)$, as $\mathrm{DW}_{\mathrm{HM}}=$ total dry weight of the plant treated with heavy metals, and $\mathrm{DW}_{\text {control }}=$ total dry weight of the control plant.

Statistical Analysis: Used the completely randomized design (CRD) as a two-factor factorial experiments, each factor had five levels with three replicates $(5 \times 5 \times 3)$, and the results were analyzed using SAS system version 9.0 by applying CARDS orders for statistical analyzes required, the Duncan's multiple-range test was used to compare the means values at a probability level 5\%.

\section{RESULTS AND DISCUSSION}

Effect of $\mathrm{Cd}$ and $\mathrm{Pb}$ on dry weight of stems: The results of Duncan's multiple range test (Table 2) showed a decrease in dry weight of stems with an increase in concentration of $\mathrm{Cd}$ and $\mathrm{Pb}$ in the soil, as for effect of interaction between $\mathrm{Cd}$ and $\mathrm{Pb}$, it appears that the highest value of dry weight of the stems was $71.067 \mathrm{~g}$ at the control which exceeded significantly the smallest value of dry weight of stems was $31.967 \mathrm{~g}$ at the interaction $(110 \mathrm{Cd}$ and $550 \mathrm{~Pb})$ $\mathrm{mg} \mathrm{kg}^{-1}$ and dry weight of stems of $40.033 \mathrm{~g}$ at the interaction (110 Cd and zero $\mathrm{Pb}) \mathrm{mg} \mathrm{kg}^{-1}$, and no significant difference was observed between the control and the value $62.933 \mathrm{~g}$, at the interaction ( $550 \mathrm{~Pb}$ and zero $\mathrm{Cd}$ ) $\mathrm{mg} \mathrm{kg}^{-1}$, the results of this study were lower than the results of Shah et al. (52) in their study on Eucalyptus camaldulensis seedlings, which showed that the highest dry weight value of stems reached $166 \mathrm{~g}$ at the control and significantly exceeded the smallest value $97 \mathrm{~g}$ at the interaction $(0.40 \mathrm{Cd}$ and $8 \mathrm{Cr}$ ) $\mathrm{mg} \mathrm{L}^{-1}$, and the results of this study are close to the values of Bajwa (9) in his study on seedlings of Eucalyptus tereticornis, Leucaena leucocephala, Melia azedarach and Dalbergia sissoo which Malted with $\mathrm{Cd}$ concentrations 0 , 10, 20, 40, 80 and 120 and $\mathrm{Pb}$ concentrations 0 , $30,60,120,180$ and $240 \mathrm{mg} \mathrm{kg}^{-1}$ dry soil, which showed in Eucalyptus seedlings that the highest dry weight of stems reached $91.4 \mathrm{~g}$ at the control and dry weight of stems was $55.9 \mathrm{~g}$ at the level of $120 \mathrm{Cd}$, the minimum dry weight of the stems was $45.9 \mathrm{~g}$ at a $\mathrm{Pb}$ level of $240 \mathrm{mg} \mathrm{kg}^{-1}$. The reason for the decrease in dry weight of stems at high concentrations of $\mathrm{Cd}$ and $\mathrm{Pb}$ may be attributed to cellular stress that affected the reduction in growth in tissue cells, reduced cell expansion and inhibition, prolongation by inhibiting heavy metals to the action of the proton pump responsible for gradually accumulating protein across the biofilm and thus reducing plant growth $(12,20)$.

Effect of $\mathrm{Cd}$ and $\mathrm{Pb}$ on dry weight of leaves: The results of Duncan's multiple range test (Table 3) showed a decrease in dry weight of leaves with an increase in the concentrations of $\mathrm{Cd}$ and $\mathrm{Pb}$ in the soil, while the effect of the interaction of $\mathrm{Cd}$ and $\mathrm{Pb}$ shows that dry weight of leaves reached $51.033 \mathrm{~g}$ at the control which significantly exceeded the smallest value for leaves dry weight of $16.033 \mathrm{~g}$ at the interaction $(110 \mathrm{Cd}$ and $550 \mathrm{~Pb}) \mathrm{mg} \mathrm{kg}^{-1}$, and for a dry weight of leaves of $29.367 \mathrm{~g}$ at the interaction (110 Cd and zero $\mathrm{Pb}) \mathrm{mg} \mathrm{kg}^{-1}$, while no significant difference was observed with the value $50.267 \mathrm{~g}$ at the interaction (550 $\mathrm{Pb}$ and zero $\mathrm{Cd}$ ) $\mathrm{mg} \mathrm{kg}^{-1}$, and the results of this study are close to the results of Bajwa (9), which showed in Eucalyptus seedlings that the highest value for leaves dry weight was $92.8 \mathrm{~g}$ 
at a concentration of $\mathrm{Cd} 10 \mathrm{mg} \mathrm{kg}^{-1}$ dry soil, and the smallest value was for dry weight for leaves it was $55.9 \mathrm{~g}$ at the level of $\mathrm{Cd} 120 \mathrm{mg}$ $\mathrm{kg}^{-1}$, the smallest value for dry weight of leaves was $37.7 \mathrm{~g}$ at the level of $\mathrm{Pb} 240 \mathrm{mg}$ $\mathrm{kg}^{-1}$, and the highest value for dry weight of leaves was $55.5 \mathrm{~g}$ at the control. The decrease in the biomass of plant leaves exposed to heavy metals may be due to poor absorption and transfer of nutrients and water from root to shoot system and between the cells of plant themselves (55).

Table 2. Duncan's multiple-range test results for effect of $\mathrm{Cd}$ and $\mathrm{Pb}$ and their interactions in dry weight of stems (g).

\begin{tabular}{|c|c|c|c|c|c|c|c|}
\hline & \multicolumn{6}{|c|}{$\begin{array}{l}\text { Interactions means in dry weight of stems (g) } \\
\text { Cd concentrations ( } \mathrm{mg} \mathrm{kg}^{-1} \text { dry soil) }\end{array}$} & \multirow[t]{2}{*}{$\mathrm{Pb}$ rates } \\
\hline \multirow{6}{*}{ 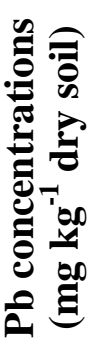 } & Levels & $\mathbf{0}$ & 25 & 55 & 85 & 110 & \\
\hline & 0 & $71.067 \mathrm{a}$ & $60.833 \mathrm{abc}$ & 59.700 bed & 64.700 abc & 40.033 ef & 59.267 a \\
\hline & 125 & $68.567 \mathrm{ab}$ & 58.833 bcd & 58.433 bcd & 64.167 abc & $38.300 \mathrm{f}$ & $57.660 \mathrm{ab}$ \\
\hline & 250 & $66.533 \mathrm{abc}$ & 57.533 bcd & 57.267 bed & 63.067 abc & $36.767 \mathrm{f}$ & $56.233 \mathrm{ab}$ \\
\hline & 450 & $67.667 \mathrm{abc}$ & $57.000 \mathrm{~cd}$ & 57.667 bcd & $48.800 \mathrm{de}$ & $36.533 \mathrm{f}$ & 53.533 bc \\
\hline & 550 & 62.933 abc & $56.400 \mathrm{~cd}$ & $56.100 \mathrm{~cd}$ & 42.433 ef & 31.967 f & $49.967 \mathrm{c}$ \\
\hline Cd & rates & $67.353 \mathrm{a}$ & 58.120 b & 57.833 b & $56.633 \mathrm{~b}$ & $36.720 \mathrm{c}$ & \\
\hline
\end{tabular}

* Rates of $\mathrm{Cd}$ or $\mathrm{Pb}$ that have the same letter are not significantly different at $(\mathrm{P} \leq \mathbf{0 . 0 0 1})$.

Table 3. Duncan's multiple-range test results for effect of $\mathrm{Cd}$ and $\mathrm{Pb}$ and their interactions in dry weight of leaves (g).

\begin{tabular}{|c|c|c|c|c|c|c|c|}
\hline \multicolumn{7}{|c|}{$\begin{array}{l}\text { Interactions means in dry weight of leaves }(\mathrm{g}) \\
\text { Cd concentrations ( } \mathrm{mg} \mathrm{kg}^{-1} \mathrm{dry} \text { soil) }\end{array}$} & \multirow[t]{2}{*}{$\mathrm{Pb}$ rates } \\
\hline & Levels & $\mathbf{0}$ & 25 & 55 & 85 & 110 & \\
\hline : & 0 & $51.033 a$ & 48.233 a-d & 42.400 a-e & 39.100 c-f & $29.367 \mathrm{fg}$ & $42.027 a$ \\
\hline 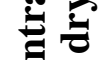 & 125 & $48.700 \mathrm{abc}$ & 44.567 a-e & 40.333 b-e & 42.167 a-e & 23.633 gh & $39.880 \mathrm{ab}$ \\
\hline$\underbrace{e}_{0}$ & 250 & 50.800 a & 45.333 a-e & 39.667 cde & 39.767 cde & $22.700 \mathrm{gh}$ & $39.653 \mathrm{ab}$ \\
\hline 80 & 450 & $52.233 \mathrm{a}$ & 38.133 def & 38.633 c-f & 35.600 ef & $18.367 \mathrm{~h}$ & $36.593 \mathrm{bc}$ \\
\hline & 550 & $50.267 \mathrm{ab}$ & 37.733 ef & 37.767 ef & $23.200 \mathrm{gh}$ & $16.033 \mathrm{~h}$ & 33.000 c \\
\hline \multicolumn{2}{|c|}{ Cd rates } & 50.607 a & $42.800 \mathrm{~b}$ & 39.760 bc & $35.967 \mathrm{c}$ & $22.020 \mathrm{~d}$ & \\
\hline
\end{tabular}

* Rates of $\mathrm{Cd}$ or $\mathrm{Pb}$ that have the same letter are not significantly different at $(\mathrm{P} \leq 0.001)$.

Effect of $\mathrm{Cd}$ and $\mathrm{Pb}$ on dry weight of roots: The results of Duncan's multiple range test (Table 4) showed a decrease in dry weight of roots with an increase in the concentration of $\mathrm{Cd}$ and $\mathrm{Pb}$ in the soil, as for the effect of the interaction between $\mathrm{Cd}$ and $\mathrm{Pb}$, it showed that the highest value of dry weight of roots reached $66.033 \mathrm{~g}$ at the control it significantly exceeded the smallest value of dry weight of roots of $21.667 \mathrm{~g}$ at the interaction $(110 \mathrm{Cd}$ and $550 \mathrm{~Pb})$ $\mathrm{mg} \mathrm{kg}^{-1}$ and the value of $31.467 \mathrm{~g}$ at the interaction (110 $\mathrm{Cd}$ and zero $\mathrm{Pb}) \mathrm{mg} \mathrm{kg}^{-1}$, and no significant difference was observed with the value $59.433 \mathrm{~g}$ at the interaction $(550 \mathrm{~Pb}$ and zero $\mathrm{Cd}) \mathrm{mg} \mathrm{kg}^{-1}$, and the values of this study outperformed the results reported by Nofal et al. (43) in their study on seedlings of Bauhinia purpurea $\mathrm{L}$. treatment with a mixture of $\mathrm{Pb}, \mathrm{Cd}$ and nickel concentrations 500, 50 and 25 for treatment $\mathrm{T} 1$, and 1000,100 and 50 for $\mathrm{T} 2$, 1500, 150 and 75 for T3, and 2000, 200 and 100 for $\mathrm{T} 4$ with a unit of $\mathrm{mg} \mathrm{kg}^{-1}$ dry soil respectively, as well as the control, which showed that the largest value of dry weight of roots was $6.23 \mathrm{~g}$ at the control significantly exceeded the smallest value for dry weight of roots $2.68 \mathrm{~g}$ at treatment $\mathrm{T} 4$. The direct effect of high concentrations of heavy metals caused cellular stress, which resulted in inhibition of root growth that resulted from inhibition of root cell division and reduced nutrient absorption that affected the dry mass of the roots (54). 
Table 4. Duncan's multiple-range test results for effect of $\mathrm{Cd}$ and $\mathrm{Pb}$ and their interactions in dry weight of roots $(\mathrm{g})$.

\begin{tabular}{|c|c|c|c|c|c|c|c|}
\hline \multicolumn{7}{|c|}{$\begin{array}{l}\text { Interactions means in dry weight of roots (g) } \\
\text { Cd concentrations ( } \mathrm{mg} \mathrm{kg}^{-1} \text { dry soil) }\end{array}$} & \multirow[t]{2}{*}{ Pb rates } \\
\hline & Level & $\mathbf{0}$ & 25 & 55 & 85 & 110 & \\
\hline 禺 & 0 & $66.033 \mathrm{a}$ & $64.100 \mathrm{ab}$ & 55.300 b-e & $45.900 \mathrm{e}-\mathrm{i}$ & 31.467 jkl & 52.560 a \\
\hline$\Xi$ & 125 & 59.733 abc & 56.033 a-d & $48.333 \mathrm{~d}-\mathrm{h}$ & $41.467 \mathrm{~g}-\mathrm{j}$ & $28.433 \mathrm{klm}$ & $46.800 \mathrm{~b}$ \\
\hline $\mathscr{e}^{\Phi}$ & 250 & $61.467 \mathrm{abc}$ & 52.600 c-f & $45.300 \mathrm{f}-\mathrm{i}$ & 39.167 g-j & $26.1 \mathrm{~lm}$ & $44.927 \mathrm{bc}$ \\
\hline 80 & 450 & 60.433 abc & $49.200 \mathrm{~d}-\mathrm{g}$ & 38.900 hij & 37.167 ijk & $24.567 \mathrm{~lm}$ & $42.053 c$ \\
\hline & 550 & 59.433 abc & $34.133 \mathrm{jkl}$ & $39.500 \mathrm{~g}-\mathrm{j}$ & 32.033 jkl & $21.667 \mathrm{~m}$ & $37.353 \mathrm{~d}$ \\
\hline \multicolumn{2}{|c|}{ Cd rates } & $61.420 \mathrm{a}$ & $51.213 \mathrm{~b}$ & 45.467 c & $39.147 \mathrm{~d}$ & $26.447 \mathrm{e}$ & \\
\hline
\end{tabular}

* Rates of $\mathrm{Cd}$ or $\mathrm{Pb}$ that have the same letter are not significantly different at $(\mathrm{P} \leq \mathbf{0 . 0 0 1})$.

Effect of $\mathrm{Cd}$ and $\mathrm{Pb}$ on $\mathrm{Cd}$ concentration in stems: The results of Duncan's multiple range test (Table 5) showed an increase in Cd content in stems with an increase in the concentration of $\mathrm{Cd}$ and $\mathrm{Pb}$ in the soil, and the effect of the interaction between $\mathrm{Cd}$ and $\mathrm{Pb}$ shows that the highest concentration of $\mathrm{Cd}$ in stems was $372.167 \mathrm{mg} \mathrm{kg}^{-1}$ at the interaction $(110 \mathrm{Cd}$ and $550 \mathrm{~Pb}) \mathrm{mg} \mathrm{kg}^{-1}$, it was significantly superior to all concentrations of other treatments, and the smallest content of Cd was $0.375 \mathrm{mg} \mathrm{kg}^{-1}$ at the control which did not notice a significant difference between it and the concentration of $\mathrm{Cd} 0.417 \mathrm{mg} \mathrm{kg}^{-1}$ at the interaction $(550 \mathrm{~Pb}$ and zero Cd) $\mathrm{mg} \mathrm{kg}^{-1}$, while the concentration of $\mathrm{Cd}$ was significantly higher than the concentration of $\mathrm{Cd} 178.625 \mathrm{mg} \mathrm{kg}^{-1}$ at the interaction (110 $\mathrm{Cd}$ and zero $\mathrm{Pb}$ ) $\mathrm{mg} \mathrm{kg}^{-1}$ at the control, and the study indicated that 19 interactions in which the concentration exceeded the critical limit for $\mathrm{Cd}$ (5-10) $\mu \mathrm{g} \mathrm{g}^{-1}$ dry weight $(44,51)$, the values of this study were superior to what was reported by Khamis et al. (27) in their study of Melia azedarach and Populus alba seedlings, which were treated with $\mathrm{Cd}$ concentrations $0,10,20$ and 40 and $\mathrm{Pb}$ concentrations 0, 200, 400 and $800 \mathrm{ppm}$, as they found that the highest concentration of $\mathrm{Cd}$ in stems of $\mathrm{P}$. alba seedlings was $11.5 \mathrm{mg} \mathrm{kg}^{-1}$ and in stems of $\mathrm{M}$. azedarach seedlings it reached $5.9 \mathrm{mg} \mathrm{kg}^{-1}$ in the concentration of $\mathrm{Cd} 40 \mathrm{mg} \mathrm{kg}^{-1}$ dry soil, which was superior to the smallest concentration for $\mathrm{Cd}$ whose value approached zero $\mathrm{mg} \mathrm{kg}^{-1}$ at the control. The reason for the increase in $\mathrm{Cd}$ concentration in stems of seedlings at high concentrations of $\mathrm{Cd}$ and $\mathrm{Pb}$ in the soil may be due to the fact that with the increase in the time of exposure of plant to heavy metals, the activity of the antioxidant system as well as other defenses in plant decreases, which facilitates transfer of heavy metals into the shoot to collect in the cell walls, this is one of the most important sites devoted to heavy metals (22).

Table 5. Duncan's multiple-range test results for effect of $\mathrm{Cd}$ and $\mathrm{Pb}$ and their interactions in $\mathrm{Cd}$ concentration in stems $\left(\mathrm{mg} \mathrm{kg}^{-1}\right)$.

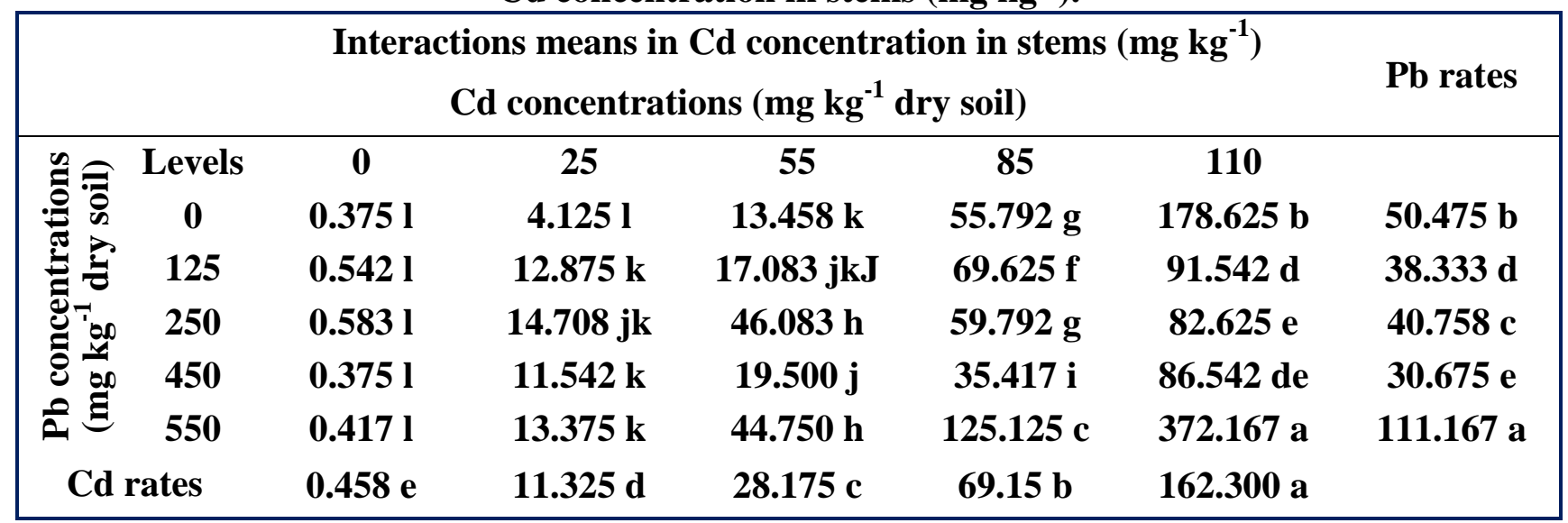

* Interactions means or rates of $\mathrm{Cd}$ or $\mathrm{Pb}$ that have the same letter are not significantly different at $(\mathrm{P} \leq \mathbf{0 . 0 0 1})$. 
Effect of $\mathrm{Cd}$ and $\mathrm{Pb}$ on $\mathrm{Cd}$ concentration in leaves: The results of Duncan's multiple range test (Table 6) showed an increase in the concentration of $\mathrm{Cd}$ in the leaves with an increase in the concentration of $\mathrm{Cd}$ and $\mathrm{Pb}$ in the soil, as for the effect of the interaction between $\mathrm{Cd}$ and $\mathrm{Pb}$, it was found that the concentration of $\mathrm{Cd}$ in the leaves reached $24.333 \mathrm{mg} \mathrm{kg}^{-1}$ at the interaction $(110 \mathrm{Cd}$ and $550 \mathrm{~Pb}) \mathrm{mg} \mathrm{kg}^{-1}$, which was significantly superior to the smallest concentration of $\mathrm{Cd}$ $0.417 \mathrm{mg} \mathrm{kg}^{-1}$ at the control, and it was found that the increase in $\mathrm{Cd}$ concentration was not significant for $0.583 \mathrm{mg} \mathrm{kg}^{-1}$ at the interaction (550 $\mathrm{Pb}$ and zero $\mathrm{Cd}$ ) $\mathrm{mg} \mathrm{kg}^{-1}$ at the control, and the Cd concentration was found $15.708 \mathrm{mg}$ $\mathrm{kg}^{-1}$ at the interaction (110 $\mathrm{Cd}$ and zero $\left.\mathrm{Pb}\right) \mathrm{mg}$ $\mathrm{kg}^{-1}$ was significantly superior to the control, and the study showed that 15 interactions in which the concentration increased beyond the critical limit of $\mathrm{Cd}(5-10) \mu \mathrm{g} \mathrm{g}^{-1}$ dry weight, and the results of this study exceeded the values of researchers El-Mahrouk et al. (17) in their study of Salix mucronate seedlings that were treated with $\mathrm{Cd}$ concentrations 0, 20, 40, 60 and 80, and $\mathrm{Cu}$ concentrations were 0,50 , 100,150 and 200, and $\mathrm{Pb}$ concentrations were $0,250,450,650$ and $850 \mathrm{mg} \mathrm{kg}^{-1}$ dry soil, which showed that the highest concentration of $\mathrm{Cd}$ in leaves approached $4 \mathrm{mg} \mathrm{kg}^{-1}$ at the level of $\mathrm{Cd} 80 \mathrm{mg} \mathrm{kg}^{-1}$ soil and significantly superior to the values of other concentrations and the smallest concentration of $\mathrm{Cd}$, which approached zero $\mathrm{mg} \mathrm{kg}^{-1}$ at the control. The reason for the increase in $\mathrm{Cd}$ concentration in seedlings' leaves with the increase in $\mathrm{Cd}$ and $\mathrm{Pb}$ concentrations in the soil is due to the possibility of plant adaptation to growth in environments contaminated with heavy metals, which enabled it to increase its resistance to some pollutants and to coexist with the new growth nature by developing antioxidants and other defense methods that block minerals, in vacuoles in plant cell walls $(14,46)$.

Table 6. Duncan's multiple-range test results for effect of $\mathrm{Cd}$ and $\mathrm{Pb}$ and their interactions in Cd concentration in leaves $\left(\mathrm{mg} \mathrm{kg}^{-1}\right)$.

\begin{tabular}{|c|c|c|c|c|c|c|c|}
\hline \multicolumn{8}{|c|}{$\begin{array}{l}\text { Interactions means in } \mathrm{Cd} \text { concentration in leaves }\left(\mathrm{mg} \mathrm{kg}^{-1}\right) \\
\text { Cd concentrations }\left(\mathrm{mg} \mathrm{kg}^{-1} \mathrm{dry} \text { soil }\right)\end{array}$} \\
\hline \multirow{6}{*}{ 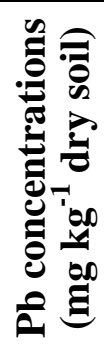 } & Level & $\mathbf{0}$ & 25 & 55 & 85 & 110 & \\
\hline & 0 & 0.417 k & $4.833 \mathrm{jk}$ & $5.333 \mathbf{j}$ & $34.542 \mathrm{e}$ & $15.708 \mathrm{~g}$ & $12.167 \mathrm{c}$ \\
\hline & 125 & $0.542 \mathrm{k}$ & $5.125 \mathbf{j}$ & 4.667 jk & $34.958 \mathrm{e}$ & 128.167 a & 34.692 a \\
\hline & 250 & 0.417 k & $4.583 \mathbf{j k}$ & 4.875 jk & 37.750 de & $13.292 \mathrm{gh}$ & $12.183 \mathrm{c}$ \\
\hline & 450 & $0.583 k$ & $6.917 \mathbf{i j}$ & 10.125 hi & $39.958 \mathrm{~d}$ & $123.833 \mathrm{~b}$ & $36.283 \mathrm{a}$ \\
\hline & 550 & $0.583 k$ & 4.583 jk & $22.125 \mathrm{f}$ & $54.833 c$ & $24.333 \mathrm{f}$ & $21.292 \mathrm{~b}$ \\
\hline \multicolumn{2}{|c|}{ Cd rates } & 0.508 e & $5.208 \mathrm{~d}$ & $9.425 \mathrm{c}$ & $40.408 \mathrm{~b}$ & $61.067 a$ & \\
\hline
\end{tabular}

* Interactions means or rates of $\mathrm{Cd}$ or $\mathrm{Pb}$ that have the same letter are not significantly different at $(\mathrm{P} \leq \mathbf{0 . 0 0 1})$.

Effect of $\mathrm{Cd}$ and $\mathrm{Pb}$ on $\mathrm{Cd}$ concentration in roots: The results of Duncan's multiple range test (Table 7) showed an increase in the $\mathrm{Cd}$ concentration in the roots with an increase in the concentration of $\mathrm{Cd}$ and $\mathrm{Pb}$ in the soil, and the effect of the interaction between $\mathrm{Cd}$ and $\mathrm{Pb}$ showed that the highest concentration of $\mathrm{Cd}$ in the roots was $162.083 \mathrm{mg} \mathrm{kg}^{-1}$ at the interaction $(110 \mathrm{Cd}$ and $550 \mathrm{~Pb}) \mathrm{mg} \mathrm{kg}^{-1}$, and it was significantly superior to all concentrations of other treatments, also the smallest concentration of Cd was $0.583 \mathrm{mg} \mathrm{kg}^{-1}$ at the control, whereas the concentration of $\mathrm{Cd}$ was $30 \mathrm{mg} \mathrm{kg}^{-1}$ at the interaction of $(110 \mathrm{Cd}$ and zero $\mathrm{Pb}) \mathrm{mg} \mathrm{kg}^{-1}$ was significantly superior to the control, and the study showed that 15 interventions in which the concentration in seedlings exceeded the critical limit of $\mathrm{Cd}(5-10) \mu \mathrm{g} \mathrm{g}^{-1}$ dry weight, and the results of this study outperformed the results reported by Khamis et al. (27) in their study of Melia azedarach and Populus alba seedlings, who observed that the highest concentration of $\mathrm{Cd}$ in roots was found in P. alba and $\mathrm{M}$. azedarach $17.5 \mathrm{mg} \mathrm{kg}^{-1}$ at a concentration of $\mathrm{Cd}$ $40 \mathrm{mg} \mathrm{kg}^{-1}$ dry soil. The reason for the increase in the concentration of $\mathrm{Cd}$ in the roots with the increase in the concentration of $\mathrm{Cd}$ and $\mathrm{Pb}$ in the soil is due to the fact that the roots of plants work to release all factors that help in the chelation and binding of minerals in the area of 
the soil close to them (28), and that most of the absorption of $\mathrm{Cd}$ occurs in The epidermis of the root cap (30), as the root cap lacks a casparian strip that controls the transport of water and salts through the cell wall cavity from the phloem to the xylem, so that $\mathrm{Cd}$ is easily transported through cell walls directly to the xylem (27).

Table 7. Duncan's multiple-range test results for effect of $\mathrm{Cd}$ and $\mathrm{Pb}$ and their interactions in Cd concentration in roots $\left(\mathrm{mg} \mathrm{kg}^{-1}\right)$.

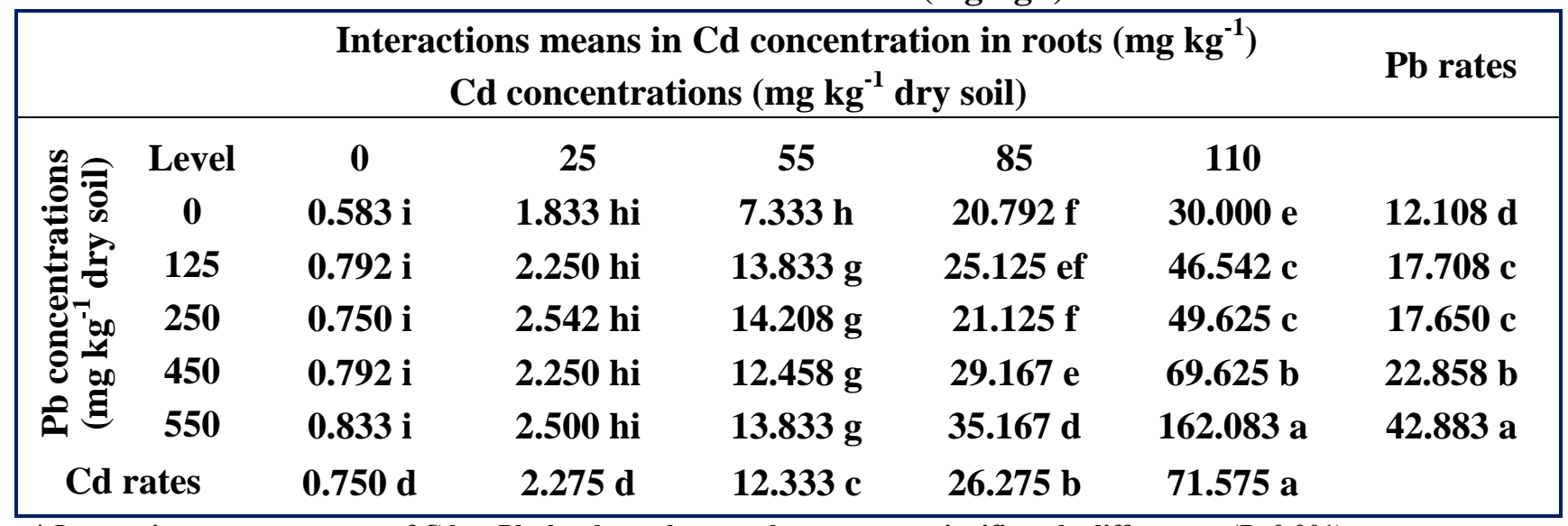

* Interactions means or rates of $\mathrm{Cd}$ or $\mathrm{Pb}$ that have the same letter are not significantly different at $(\mathrm{P} \leq \mathbf{0 . 0 0 1})$.

Effect of $\mathrm{Cd}$ and $\mathrm{Pb}$ on $\mathrm{Pb}$ concentration in stems: The results of Duncan's multiple range test (Table 8) showed an increase in the concentration of $\mathrm{Pb}$ in stems with an increase in the concentrations of $\mathrm{Cd}$ and $\mathrm{Pb}$ in the soil, while the effect of the interaction between $\mathrm{Cd}$ and $\mathrm{Pb}$ showed that the highest concentration of $\mathrm{Pb}$ in the stems was $62.375 \mathrm{mg} \mathrm{kg}^{-1}$ at the interaction $(110 \mathrm{Cd}$ and $550 \mathrm{~Pb}) \mathrm{mg} \mathrm{kg}^{-1}$ and this value was significantly superior to all the concentrations of the treatments, and the $\mathrm{Pb}$ concentration at the control treatment was $12.417 \mathrm{mg} \mathrm{kg}^{-1}$, and it was found from the results of this study that three values exceeded the critical toxic limit ( $30 \mu \mathrm{g} \mathrm{g}^{-1}$ dry weight) (47), the results of this study outperformed the results of researchers Mleczek et al. (38) in their study on seedlings of Acer platanoides
L., A. pseudoplatanus L., Betula pendula Roth, Quercus robur L., Tilia cordata Miller and Ulmus laevis Pall., which treated with mining sludge containing arsenic (As), cadmium (Cd), copper $(\mathrm{Cu})$, lead $(\mathrm{Pb})$, thallium $(\mathrm{TI})$ and zinc $(\mathrm{Zn})$ at concentrations of 18022, 1030, 4511, 3865, 669 and $1565 \mathrm{mg} \mathrm{kg}^{-1}$, respectively, results showed that the significant superiority of the $\mathrm{Pb}$ concentration that approaching 50 $\mathrm{mg} \mathrm{kg}^{-1}$ in U. laevis seedlings grown in mining sludge on all seedlings. The increase in the concentration of $\mathrm{Pb}$ in the stems at high concentrations of $\mathrm{Cd}$ and $\mathrm{Pb}$ may be due to the possibility of plant accumulation of heavy metals in the shoot due to the productivity of the vegetative biomass that supports the extraction of minerals and their confinement in cell wall vacuoles (7).

Table 8. Duncan's multiple-range test results for effect of $\mathrm{Cd}$ and $\mathrm{Pb}$ and their interactions in $\mathrm{Pb}$ concentration in stems $\left(\mathrm{mg} \mathrm{kg}^{-1}\right)$.

\begin{tabular}{|c|c|c|c|c|c|c|c|}
\hline \multirow{7}{*}{ 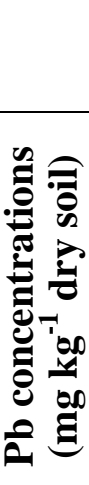 } & \multicolumn{6}{|c|}{$\begin{array}{l}\text { Interactions means in } \mathrm{Pb} \text { concentration in stems }\left(\mathrm{mg} \mathrm{kg}^{-1}\right) \\
\mathrm{Cd} \text { concentrations }\left(\mathrm{mg} \mathrm{kg}^{-1} \text { dry soil }\right)\end{array}$} & \multirow[t]{2}{*}{$\mathrm{Pb}$ rates } \\
\hline & Level & $\mathbf{0}$ & 25 & 55 & 85 & 110 & \\
\hline & $\mathbf{0}$ & 12.417 ijk & $11.000 \mathrm{k}$ & $11.167 \mathrm{k}$ & $12.458 \mathrm{ijk}$ & $9.583 \mathrm{k}$ & $11.325 \mathrm{e}$ \\
\hline & 125 & 15.292 hi & 11.625 jk & 14.708 hij & $16.958 \mathrm{gh}$ & $12.500 \mathrm{ijk}$ & $14.217 \mathrm{~d}$ \\
\hline & 250 & 22.333 def & 20.875 ef & $16.875 \mathrm{gh}$ & 33.625 b & $22.458 \mathrm{de}$ & $23.233 \mathrm{~b}$ \\
\hline & 450 & 21.125 def & $24.458 d$ & $16.250 \mathrm{gh}$ & $18.833 \mathrm{fg}$ & $18.917 \mathrm{fg}$ & $19.917 \mathrm{c}$ \\
\hline & 550 & 15.125 hij & 30.042 c & $18.917 \mathrm{fg}$ & $24.375 d$ & $62.375 \mathrm{a}$ & $30.167 a$ \\
\hline \multicolumn{2}{|c|}{ Cd rates } & $17.258 \mathrm{~d}$ & $19.600 \mathrm{c}$ & $15.583 \mathrm{e}$ & $21.250 \mathrm{~b}$ & 25.167 a & \\
\hline
\end{tabular}

* Interactions means or rates of $\mathrm{Cd}$ or $\mathrm{Pb}$ that have the same letter are not significantly different at $(\mathrm{P} \leq 0.001)$. 
Effect of $\mathrm{Cd}$ and $\mathrm{Pb}$ on $\mathrm{Pb}$ concentration in leaves: The results of Duncan's multiple range test (Table 9) showed that there are no significant differences with increasing the concentration of $\mathrm{Cd}$ and $\mathrm{Pb}$ in the soil between the concentration of $\mathrm{Pb}$ in the leaves at the control and the interactions between $\mathrm{Cd}$ and $\mathrm{Pb}$ except for the two interactions (85 $\mathrm{Cd}$ and zero $\mathrm{Pb})$ and $(85 \mathrm{Cd}$ and $250 \mathrm{~Pb}) \mathrm{mg} \mathrm{kg}^{-1}$ when the concentration of $\mathrm{Pb}$ in leaves decreased significantly compared to the control, while the effect of the interaction between $\mathrm{Cd}$ and $\mathrm{Pb}$ showed that the highest concentration of $\mathrm{Pb}$ in the leaves was $20.417 \mathrm{mg} \mathrm{kg}^{-1}$ at the interaction $(110 \mathrm{Cd}$ and $550 \mathrm{~Pb}) \mathrm{mg} \mathrm{kg}^{-1}$ and did not differ significantly from the control value $(18.375 \mathrm{mg}$ $\mathrm{kg}^{-1}$ ), and the results of this study were lower than the results of researchers Mleczek et al. (38) whose findings showed a clear significant superiority over all types of seedlings for the concentration of $\mathrm{Pb}$ whose value approached 50 $\mathrm{mg} \mathrm{kg}^{-1}$ in the leaves of Ulmus laevis Pall. seedlings growing in mining sludge. The low movement of $\mathrm{Pb}$ from soil to leaves was the reason for the absence of significant differences between most of the interactions.

Table 9. Duncan's multiple-range test results for effect of $\mathrm{Cd}$ and $\mathrm{Pb}$ and their interactions in $\mathrm{Pb}$ concentration in leaves $\left(\mathrm{mg} \mathrm{kg}^{-1}\right)$.

\begin{tabular}{|c|c|c|c|c|c|c|c|}
\hline \multirow{7}{*}{ 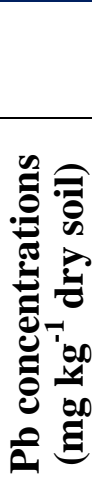 } & \multicolumn{6}{|c|}{$\begin{array}{l}\text { Interactions means in } \mathrm{Pb} \text { concentration in leaves }\left(\mathrm{mg} \mathrm{kg}^{-1}\right) \\
\mathrm{Cd} \text { concentrations }\left(\mathrm{mg} \mathrm{kg}^{-1} \mathrm{dry} \text { soil }\right)\end{array}$} & \multirow[t]{2}{*}{$\mathrm{Pb}$ rates } \\
\hline & Level & $\mathbf{0}$ & 25 & 55 & 85 & 110 & \\
\hline & 0 & 18.375 a-d & 17.750 a-d & 14.500 cde & $10.042 \mathrm{f}$ & 16.292 a-d & $15.392 \mathrm{~b}$ \\
\hline & 125 & 14.625 cde & 20.042 ab & 14.667 cde & 15.833 bcd & $18.667 \mathrm{abc}$ & $16.767 \mathrm{ab}$ \\
\hline & 250 & 16.250 a-d & 16.625 a-d & 18.042 a-d & 11.125 ef & 17.958 a-d & $16.000 \mathrm{~b}$ \\
\hline & 450 & 14.792 cde & 14.125 de & 18.125 a-d & 16.333 a-d & $19.542 \mathrm{ab}$ & $16.583 \mathrm{ab}$ \\
\hline & 550 & 14.292 cde & $19.917 \mathrm{ab}$ & 17.333 a-d & 18.792 abc & 20.417 a & $18.150 \mathrm{a}$ \\
\hline \multicolumn{2}{|c|}{ Cd rates } & $15.667 \mathrm{~cd}$ & $17.692 \mathrm{ab}$ & $16.533 \mathrm{bc}$ & $14.425 \mathrm{~d}$ & $18.575 \mathrm{a}$ & \\
\hline
\end{tabular}

* Interactions means that have the same letter are not significantly different at $(\mathbf{P} \leq 0.01)$.

* Rates of Cd that have the same letter are not significantly different at $(\mathbf{P} \leq \mathbf{0 . 0 0 1})$.

* Rates of $\mathbf{P b}$ that have the same letter are not significantly different at $(\mathbf{P} \leq \mathbf{0 . 0 5})$.

Effect of $\mathrm{Cd}$ and $\mathrm{Pb}$ on $\mathrm{Pb}$ concentration in roots: The results of Duncan's multiple range test (Table 10) showed that the concentration of $\mathrm{Pb}$ increases with the increasing the concentration of $\mathrm{Cd}$ and $\mathrm{Pb}$ in the soil, as for the effect of the interaction between $\mathrm{Cd}$ and $\mathrm{Pb}$, it appears that the $\mathrm{Pb}$ concentration in the roots was $24.958 \mathrm{mg} \mathrm{kg}^{-1}$ at the interaction of $(110 \mathrm{Cd}$ and $550 \mathrm{~Pb}) \mathrm{mg} \mathrm{kg}^{-1}$, which It significantly exceeded the smallest value of the $\mathrm{Pb}$ concentration $\left(2.875 \mathrm{mg} \mathrm{kg}^{-1}\right)$ at the control, also $\mathrm{Pb}$ concentration was $34.417 \mathrm{mg}$ $\mathrm{kg}^{-1}$ at the interaction (550 $\mathrm{Pb}$ and zero $\mathrm{Cd}$ ) $\mathrm{mg}$ $\mathrm{kg}^{-1}$ was significantly superior to the control, concentrations of $\mathrm{Pb}$ exceeded $30 \mu \mathrm{g} \mathrm{g}^{-1}$ dry weight, which is the critical toxic limit for most plants, the results of this study were lower than the results of researchers Mleczek et al. (38), whose values showed that the highest concentration of $\mathrm{Pb}$ in the roots approached $600 \mathrm{mg} \mathrm{kg}^{-1}$ in Acer platanoides seedlings developing in mining sludge, which was not observed significant difference with $\mathrm{Pb}$ concentration in roots of Quercus robur and Ulmus laevis grown in mining sludge while it outperformed all other concentrations in seedlings. The reason for the increase in $\mathrm{Pb}$ concentration in the roots of seedlings with the increase in the concentration of $\mathrm{Cd}$ and $\mathrm{Pb}$ in the soil is due to the plant's resistance to the stress of heavy metals through the formation of complexes that work to encapsulate and isolate heavy metals in the root cell vacuoles that have been identified as a detoxification mechanism, as the inner dermis is one of the most important sites for concentrating heavy metals in the roots $(53,33)$.

Effect of $\mathbf{C d}$ and $\mathrm{Pb}$ on TF of $\mathrm{Cd}$ : The results of Duncan's multiple range test (Table 11) showed that most of TF values of $\mathrm{Cd}$ increased in the seedlings with an increase in the concentration of $\mathrm{Cd}$ and $\mathrm{Pb}$ in the soil, as for the effect of the interaction between $\mathrm{Cd}$ and $\mathrm{Pb}$, it appears that TF value reached 1.224 at the 
interaction $(110 \mathrm{Cd}$ and $550 \mathrm{~Pb}) \mathrm{mg} \mathrm{kg}^{-1}$, and value of TF was 0.783 at the control, and it was noticed that there was no significant difference between the control and the TF value (0.621) at the interaction between $(550 \mathrm{~Pb}$ and zero $\mathrm{Cd})$ $\mathrm{mg} \mathrm{kg}$ while value of TF was significantly superior to 3.245 at the interaction between $(110 \mathrm{Cd}$ and zero $\mathrm{Pb}) \mathrm{mg} \mathrm{kg}^{-1}$ at the control, the values of this study outperformed the results of El-Mahrouk et al. (17) in their study on Salix mucronate seedlings, as $\mathrm{TF}$ for $\mathrm{Cd}$ reached 76.91 at the control, and $\mathrm{TF}$ value for $\mathrm{Cd}$ exceeded 76.68 at the level of $\mathrm{Cd} 60 \mathrm{mg} \mathrm{kg}^{-1}$ soil significantly on TF values for $\mathrm{Cd}$ and for value is 69.12 at the level of $\mathrm{Cd} 80 \mathrm{mg} \mathrm{kg}^{-1}$ soil and the lowest value for $\mathrm{TF}$ for $\mathrm{Cd}$ is 28.08 at the level of $\mathrm{Cd} 20 \mathrm{mg} \mathrm{kg}^{-1}$ soil. The results of this study showed that the seedlings were able to transfer $\mathrm{Cd}$ and collect it from the roots to the shoot, as $\mathrm{TF}$ value of $\mathrm{Cd}$ was $(>1)$ for most seedlings, and this means the ability of the seedlings to accumulate $\mathrm{Cd}$ in its shoots, as the transfer of heavy metals from root to shoot depends on the environment and soil that determine the availability of heavy metals, and type of the plant, and the plant considered a hyperaccumulator for HM if the value was $(>1)$ for TF (31).

Table 10. Duncan's multiple-range test results for effect of $\mathrm{Cd}$ and $\mathrm{Pb}$ and their interactions in $\mathrm{Pb}$ concentration in roots $\left(\mathrm{mg} \mathrm{kg}^{-1}\right)$.

\begin{tabular}{|c|c|c|c|c|c|c|c|}
\hline \multicolumn{7}{|c|}{$\begin{array}{l}\text { Interactions means in } \mathrm{Pb} \text { concentration in roots }\left(\mathrm{mg} \mathrm{kg}^{-1}\right) \\
\quad \mathrm{Cd} \text { concentrations }\left(\mathrm{mg} \mathrm{kg}^{-1} \text { dry soil }\right)\end{array}$} & $\mathrm{Pb}$ rates \\
\hline \multirow{6}{*}{ 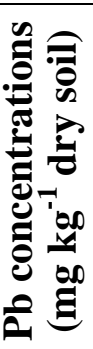 } & Level & $\mathbf{0}$ & 25 & 55 & 85 & 110 & \\
\hline & $\mathbf{0}$ & 2.8751 & 7.750 h-k & 5.875 jkl & $4.458 \mathrm{kl}$ & 7.083 i-l & $5.608 \mathrm{e}$ \\
\hline & 125 & $4.917 \mathrm{kl}$ & $11.833 \mathrm{gh}$ & 7.500 h-k & $12.458 \mathrm{~g}$ & 11.000 ghi & $9.542 \mathrm{~d}$ \\
\hline & 250 & $9.625 \mathrm{~g}-\mathrm{j}$ & $11.958 \mathrm{gh}$ & $13.958 \mathrm{fg}$ & 9.708 g-j & $73.500 a$ & $23.750 \mathrm{~b}$ \\
\hline & 450 & $49.583 \mathrm{~b}$ & $17.750 \mathrm{f}$ & $11.667 \mathrm{gh}$ & $29.875 d$ & $48.750 \mathrm{~b}$ & $31.525 \mathrm{a}$ \\
\hline & 550 & 34.417 c & $13.083 \mathrm{~g}$ & 10.792 ghi & $13.500 \mathrm{~g}$ & $24.958 \mathrm{e}$ & $19.350 \mathrm{c}$ \\
\hline \multicolumn{2}{|c|}{ Cd rates } & $20.283 \mathrm{~b}$ & $12.475 \mathrm{c}$ & $9.958 \mathrm{~d}$ & $14.000 \mathrm{c}$ & 33.058 a & \\
\hline
\end{tabular}

* Interactions means or rates of $\mathrm{Cd}$ or $\mathrm{Pb}$ that have the same letter are not significantly different at $(\mathrm{P} \leq 0.001)$.

Table 11. Duncan's multiple-range test results for effect of $\mathrm{Cd}$ and $\mathrm{Pb}$ and their interactions in TF of Cd.

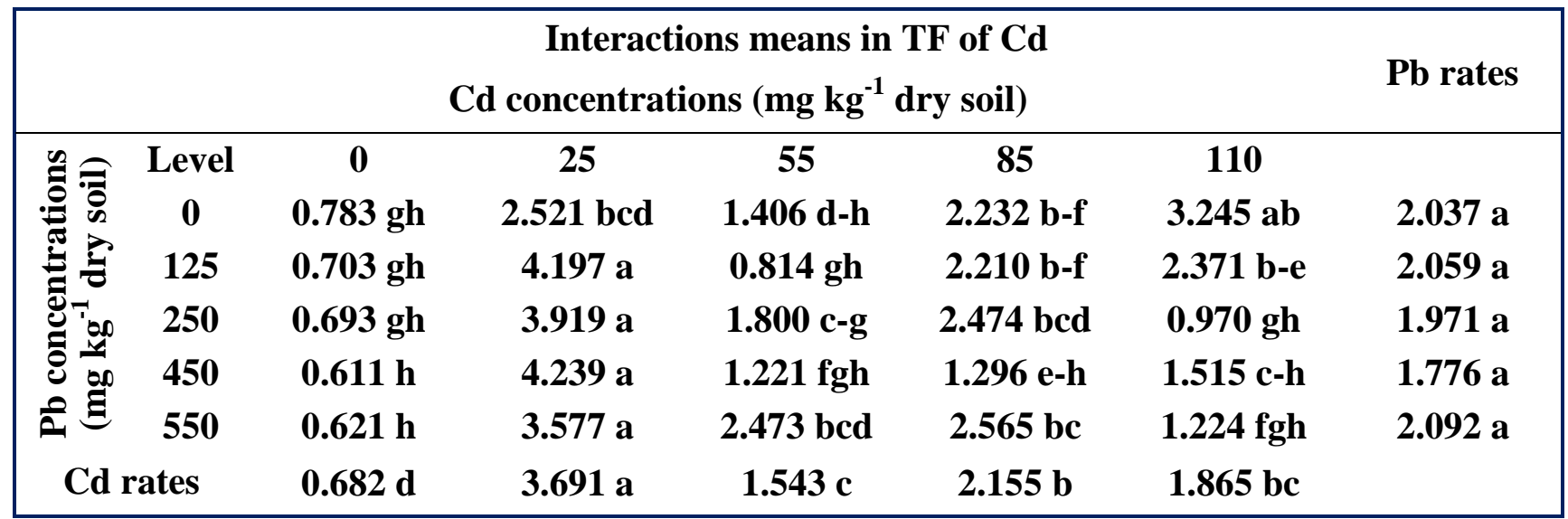

* Interactions means or rates of $\mathrm{Cd}$ that have the same letter are not significantly different at $(\mathrm{P} \leq \mathbf{0 . 0 0 1})$.

Effect of $\mathrm{Cd}$ and $\mathrm{Pb}$ on $\mathrm{BAC}$ of $\mathrm{Cd}$ : The results of Duncan's multiple range test (Table 12) showed that most of the BAC values of $\mathrm{Cd}$ increased in seedlings with increasing the concentration of $\mathrm{Cd}$ and $\mathrm{Pb}$ in the soil, while the effect of the interaction between $\mathrm{Cd}$ and $\mathrm{Pb}$ showed that the highest value of BAC was 28.790 at the interaction $(110 \mathrm{Cd}$ and zero $\mathrm{Pb}$ ) $\mathrm{mg} \mathrm{kg}^{-1}$ was superior significantly for all BAC values of $\mathrm{Cd}$, and that $\mathrm{BAC}$ value of 20.597 at the interaction $(110 \mathrm{Cd}$ and $550 \mathrm{~Pb}) \mathrm{mg} \mathrm{kg}^{-1}$ significantly exceeded value 2.106 at the control, while no significant difference was observed between value of 1.333 at the interaction $(550 \mathrm{~Pb}$ and zero Cd) $\mathrm{mg} \mathrm{kg}^{-1}$ at the control, and the values of this study outperformed the results of 
$\mathrm{Ng}$ et al. (41) in their study on the vegetative accumulation of heavy metals in the soil, as they found in Imperata cylindrica plant that BAC value of $\mathrm{Cd}$ reached 1.519 at the control did not differ significantly from value 1.343 at a level of Cd $15 \mathrm{mg} \mathrm{kg}^{-1}$ soil, while it was found in Pennisetum purpureum that $\mathrm{BAC}$ value of $\mathrm{Cd}$ was 2.163 at a level of $\mathrm{Cd} 15 \mathrm{mg} \mathrm{kg}^{-1}$ dry soil, and it significantly exceeded value 1.055 at the control. The transport of heavy metals from the soil to the shoot through the roots depends on the environment of the plant and the soil that determines the availability of heavy metals, and the plants with a value $(>1)$ for BAC were considered to be an hyperaccumulator of heavy metals (31), and plant extraction efficiency is related to mineral concentration in plant and dry matter productivity, in order for the plant to be ideal in phytoremediation of a polluted site, it must have high biomass productivity and the ability to withstand and accumulate mineral pollutants (56).

Table 12. Duncan's multiple-range test results for effect of $\mathrm{Cd}$ and $\mathrm{Pb}$ and their interactions in BAC of Cd.

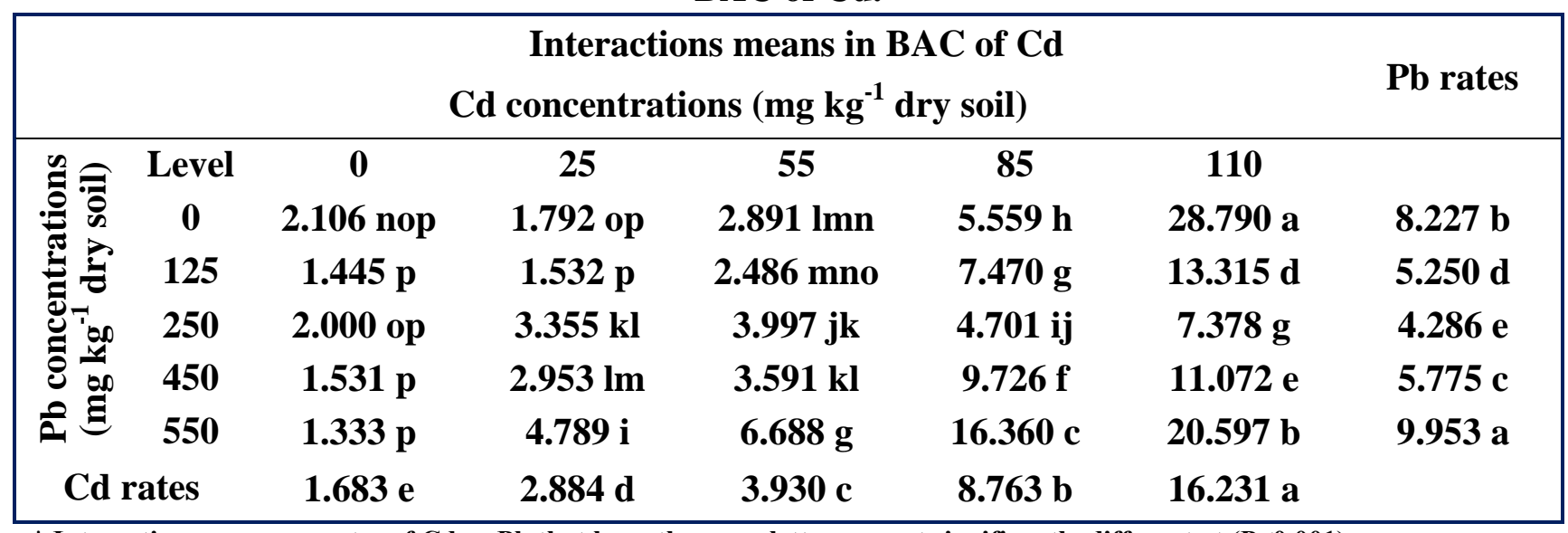

* Interactions means or rates of $\mathrm{Cd}$ or $\mathrm{Pb}$ that have the same letter are not significantly different at $(\mathrm{P} \leq \mathbf{0 . 0 0 1})$.

Effect of $\mathrm{Cd}$ and $\mathrm{Pb}$ on $\mathrm{BCF}$ of $\mathrm{Cd}$ : The results of Duncan's multiple range test (Table 13) showed that most of $B C F$ values increased for $\mathrm{Cd}$ in seedlings with an increase in the concentration of $\mathrm{Cd}$ and $\mathrm{Pb}$ in the soil, as for the effect of the interaction between $\mathrm{Cd}$ and $\mathrm{Pb}$, it appears that the highest value of $\mathrm{BCF}$ was 16.840 at the interaction $(110 \mathrm{Cd}$ and 550 $\mathrm{Pb}) \mathrm{mg} \mathrm{kg}^{-1}$, It significantly exceeded all BCF values and 3.111 at the control, and $\mathrm{BCF}$ value of 8.889 at the interaction $(110 \mathrm{Cd}$ and zero $\mathrm{Pb}) \mathrm{mg} \mathrm{kg}^{-1}$ outperformed over the control, while no significant difference was observed between the $\mathrm{BCF}$ value of 2.222 at the interaction (550 $\mathrm{Pb}$ and zero $\mathrm{Cd}$ ) $\mathrm{mg} \mathrm{kg}^{-1}$ at the control, and the values of this study outperformed the results of El-Mahrouk et al. (17) in their study on Salix mucronate seedlings, which showed that $\mathrm{BCF}$ value for $\mathrm{Cd}$ was 0.27 at the control and the highest value for $\mathrm{BCF}$ for $\mathrm{Cd}$ was 0.61 when the level of $\mathrm{Cd}$ was $80 \mathrm{mg} \mathrm{kg}^{-1}$ dry soil, which significantly outperformed all BCF values for $\mathrm{Cd}$. The value of BCF in a plant depends on the type of mineral ion and its concentration in the soil as well as on the type of plant and the surrounding environmental conditions (25). A plant with a $\mathrm{BCF}$ value (more than one) is suitable for phytoremediation of the soils contaminated with heavy metals $(35,39)$.

Effect of $\mathrm{Cd}$ and $\mathrm{Pb}$ on $\mathrm{CI}$ of $\mathrm{Cd}$ : The results of Duncan's multiple range test (Table 14) showed that $\mathrm{CI}$ values of $\mathrm{Cd}$ increased in the seedlings with an increase in the concentration of $\mathrm{Cd}$ and $\mathrm{Pb}$ in the soil, while the effect of the interaction between $\mathrm{Cd}$ and $\mathrm{Pb}$ showed that the highest CI value was 490.812 when the interaction $(110 \mathrm{Cd}$ and $550 \mathrm{~Pb}) \mathrm{mg} \mathrm{kg}^{-1}$ and this value was superior significantly on all the interference values, and the CI of 184.298 at the interaction (110 $\mathrm{Cd}$ and zero $\mathrm{Pb}) \mathrm{mg} \mathrm{kg}^{-1}$ significantly exceeded on the control, and the results of this study surpassed the results of Chandra and Hoduck (11), in their study of the effect of a mixture of $\mathrm{Cu}, \mathrm{Cd}, \mathrm{Cr}$ and $\mathrm{Zn}$ at concentrations of $0,5,50,100,200$ and 500 $\mathrm{mg} \mathrm{L}^{-1}$ on four different poplar hybrids, the results showed that the highest $\mathrm{CI}$ value for $\mathrm{Cd}$ was 35.69 when interfering $500 \mathrm{mg} \mathrm{L}^{-1}$ for $\mathrm{Cd}$, $\mathrm{Zn}, \mathrm{Cu}$ and $\mathrm{Cr}$ in the TD225 hybrid, which significantly outperformed all other the hybrids values. 
Table 13. Duncan's multiple-range test results for effect of $\mathrm{Cd}$ and $\mathrm{Pb}$ and their interactions in BCF of Cd.

\begin{tabular}{|c|c|c|c|c|c|c|c|}
\hline & & & $\begin{array}{r}\text { Interac } \\
\text { concentr }\end{array}$ & $\begin{array}{l}\text { s means in } \\
\text { ns (mg kg }\end{array}$ & $\begin{array}{l}\text { F of Cd } \\
\text { y soil) }\end{array}$ & & $\mathrm{Pb}$ rates \\
\hline & Levels & 0 & 25 & 55 & 85 & 110 & \\
\hline : & 0 & 3.111 ef & $0.733 \mathrm{i}$ & $2.257 \mathrm{fgh}$ & $2.559 \mathrm{fg}$ & 8.889 b & $3.510 \mathrm{c}$ \\
\hline 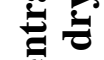 & 125 & $2.111 \mathrm{fgh}$ & 0.383 i & 3.162 ef & $3.589 \mathrm{e}$ & $5.641 d$ & $2.977 \mathrm{~d}$ \\
\hline שֶ & 250 & 3.000 efg & 0.884 i & $2.229 \mathrm{fgh}$ & $2.036 \mathrm{gh}$ & $7.634 \mathrm{c}$ & $3.157 \mathrm{~cd}$ \\
\hline 8 & 450 & $2.533 \mathrm{fg}$ & $0.720 \mathrm{i}$ & $3.020 \mathrm{efg}$ & $7.527 \mathrm{c}$ & $7.329 \mathrm{c}$ & $4.226 \mathrm{~b}$ \\
\hline & 550 & $2.222 \mathrm{fgh}$ & $1.333 \mathrm{hi}$ & $2.767 \mathrm{efg}$ & $6.394 \mathrm{~d}$ & $16.840 \mathrm{a}$ & 5.911 a \\
\hline Cd & rates & $2.596 \mathrm{c}$ & $0.811 d$ & $2.687 \mathrm{c}$ & $4.421 \mathrm{~b}$ & $9.267 \mathrm{a}$ & \\
\hline
\end{tabular}

* Interactions means or rates of $\mathrm{Cd}$ or $\mathrm{Pb}$ that have the same letter are not significantly different at $(\mathrm{P} \leq 0.001)$.

Table 14. Duncan's multiple-range test results for effect of $\mathrm{Cd}$ and $\mathrm{Pb}$ and their interactions in CI of Cd.

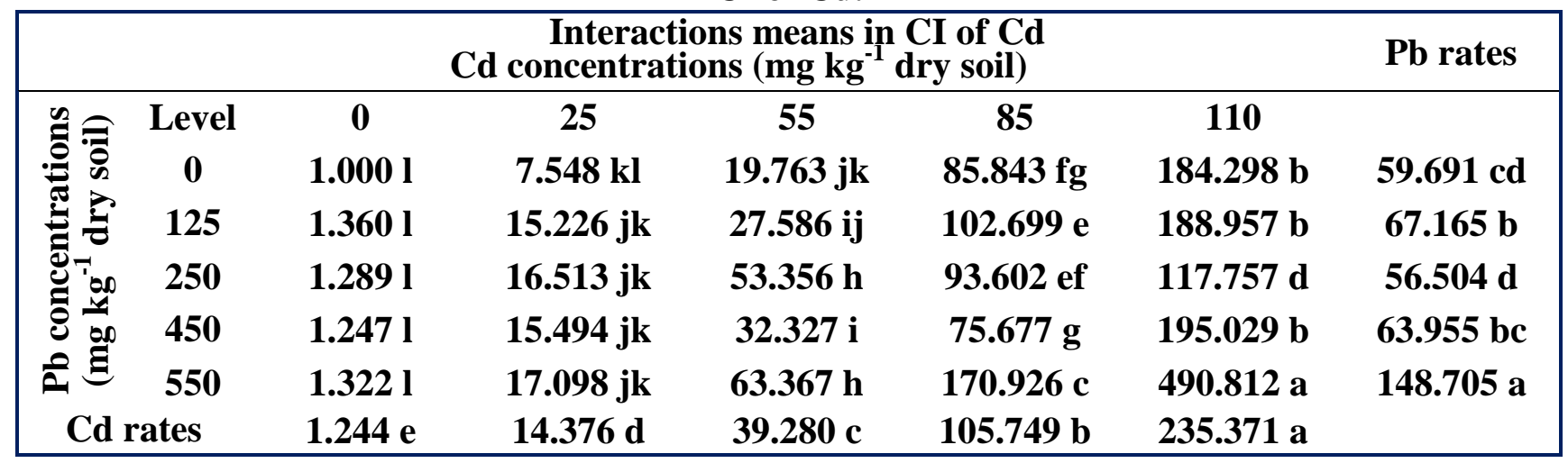

* Interactions means or rates of $\mathrm{Cd}$ or $\mathrm{Pb}$ that have the same letter are not significantly different at $(\mathrm{P} \leq 0.001)$.

Effect of $\mathrm{Cd}$ and $\mathrm{Pb}$ on $\mathrm{TF}$ of $\mathrm{Pb}$ : From the results of Duncan's multiple range test (Table 15), it appears that the highest value of TF for $\mathrm{Pb}$ was 5.702 at the control which was significantly superior to all other TF values, and the value was 1.675 at the interaction $(110 \mathrm{Cd}$ and $550 \mathrm{~Pb}) \mathrm{mg}$ $\mathrm{kg}^{-1}$, which was significantly higher on the TF value of 0.431 at the interaction $(550 \mathrm{~Pb}$ and zero Cd) $\mathrm{mg} \mathrm{kg}^{-1}$, also the control value significantly outperformed the TF value of 0.431 at the interaction (550 $\mathrm{Pb}$ and zero $\mathrm{Cd}) \mathrm{mg} \mathrm{kg}^{-1}$ and the TF value of 1.879 at the interaction (110 $\mathrm{Cd}$ and zero $\mathrm{Pb}$ ) $\mathrm{mg} \mathrm{kg}^{-1}$, the values of this study were close to the results of researchers Abbasi et al. (1) in their study on Acer cappadocicum, Fraxinus excelsior and Platycladus orientalis seedlings, the results showed that in F. excelsior seedlings TF value for $\mathrm{Pb}$, which approached 1.8 at the control, exceeded all $\mathrm{TF}$ values at $\mathrm{Pb}$ levels, except $\mathrm{Pb}$ level $200 \mathrm{mg} \mathrm{kg}^{-1}$, whereas the smallest value for TF, which approached 0.8 , was at the $\mathrm{Pb}$ level $400 \mathrm{mg} \mathrm{kg}^{-1}$. The results of this study indicates the ability of the seedlings to transfer $\mathrm{Pb}$ from the root system and collect it in the shoot, as the value of TF $(>1)$ was for most seedlings, and this explains the ability of seedlings to accumulate heavy metals in their shoot, and the reason is due to the existence of an effective mechanism for excessive accumulation on the studied seedlings, which allow the absorption and accumulation of heavy metals from contaminated soil to root and then to shoot $(1,34)$.

Effect of $\mathrm{Cd}$ and $\mathrm{Pb}$ on $\mathrm{BAC}$ of $\mathrm{Pb}$ : The results of Duncan's multiple range test (Table 16) showed that most of BAC values for $\mathrm{Pb}$ in seedlings increased with the increasing of $\mathrm{Cd}$ and $\mathrm{Pb}$ concentration in the soil, as for effect of the interaction between $\mathrm{Cd}$ and $\mathrm{Pb}$, it appears that the highest $\mathrm{BAC}$ value for $\mathrm{Pb}$ was 4.246 at the interaction $(110 \mathrm{Cd}$ and $550 \mathrm{~Pb}) \mathrm{mg} \mathrm{kg}^{-1}$, and significantly exceeded all the interference values, and the BAC value reached 1.579 at the control which significantly exceeded BAC value for $\mathrm{Pb}$ of 1.293 at the interaction $(550 \mathrm{~Pb}$ and zero Cd) $\mathrm{mg} \mathrm{kg}^{-1}$, and the value of 0.884 at the interaction (110 Cd and zero $\mathrm{Pb}) \mathrm{mg} \mathrm{kg}^{-1}$, and the values of this study outperformed the results 
of $\mathrm{Ng}$ et al. (41), which showed in Imperata cylindrica that $\mathrm{BAC}$ value for $\mathrm{Pb}$ was 0.138 at the control which did not differ significantly from the value 0.359 at the level of $\mathrm{Pb} 140 \mathrm{mg}$ $\mathrm{kg}^{-1}$ dry soil, while the researchers noted in Pennisetum purpureum, BAC value for $\mathrm{Pb}$ was 0.436 at a $\mathrm{Pb}$ level of $140 \mathrm{mg} \mathrm{kg}^{-1}$ dry soil, and it significantly exceeded the value 0.122 at the control. The accumulation of $\mathrm{Cd}, \mathrm{Cu}$ and $\mathrm{Pb}$ in the shoot depends on the level of their concentrations in the root zone, $\mathrm{pH}$ in the soil, the type of plant, and the surrounding environment (17).

Table 15. Duncan's multiple-range test results for effect of $\mathrm{Cd}$ and $\mathrm{Pb}$ and their interactions in TF of $\mathbf{P b}$.

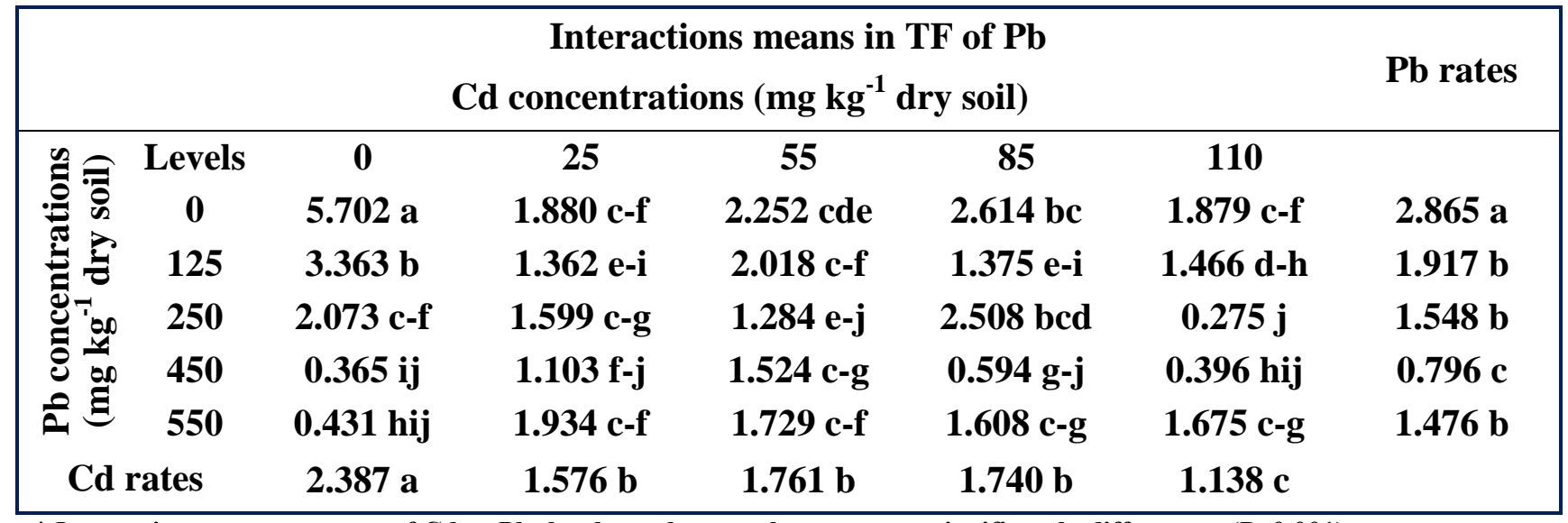

* Interactions means or rates of $\mathrm{Cd}$ or $\mathrm{Pb}$ that have the same letter are not significantly different at $(\mathrm{P} \leq 0.001)$.

Table 16. Duncan's multiple-range test results for effect of $\mathrm{Cd}$ and $\mathrm{Pb}$ and their interactions in $\mathrm{BAC}$ of $\mathbf{P b}$.

\begin{tabular}{|c|c|c|c|c|c|c|c|}
\hline & & & $\begin{array}{l}\text { Interact } \\
\text { concentra }\end{array}$ & $\begin{array}{l}\text { s means in } \\
\text { ns ( } \mathrm{mg} \mathrm{kg}^{-1}\end{array}$ & $\begin{array}{l}\mathrm{AC} \text { of } \mathrm{Pb} \\
\text { y soil) }\end{array}$ & & $\mathrm{Pb}$ rates \\
\hline & Level & $\mathbf{0}$ & 25 & 55 & 85 & 110 & \\
\hline : & 0 & 1.579 efg & 1.475 ghi & $1.053 \mathrm{klm}$ & $0.769 \mathrm{n}$ & $0.884 \mathrm{mn}$ & $1.152 \mathrm{c}$ \\
\hline$\stackrel{\Xi}{\Xi}$ & 125 & $1.228 \mathrm{i}-\mathrm{l}$ & $1.146 \mathrm{kl}$ & $1.205 \mathrm{jkl}$ & $0.961 \mathrm{lmn}$ & $1.598 \mathrm{~d}-\mathrm{g}$ & $1.228 \mathrm{c}$ \\
\hline 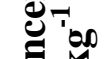 & 250 & $1.583 \mathrm{efg}$ & $1.923 \mathrm{bc}$ & 1.433 g-j & $1.530 \mathrm{fgh}$ & $2.073 \mathrm{~b}$ & $1.708 \mathrm{~b}$ \\
\hline 80 & 450 & 1.842 b-e & $1.978 \mathrm{bc}$ & $1.763 \mathrm{c}-\mathrm{f}$ & 1.203 jkl & 1.820 b-e & $1.721 \mathrm{~b}$ \\
\hline & 550 & $1.293 \mathrm{~h}-\mathrm{k}$ & $2.050 \mathrm{~b}$ & $1.859 \mathrm{bcd}$ & $1.771 \mathrm{c}-f$ & $4.246 \mathrm{a}$ & $2.244 \mathrm{a}$ \\
\hline Cd & ates & $1.505 \mathrm{c}$ & $1.714 \mathrm{~b}$ & $1.462 \mathrm{c}$ & $1.247 \mathrm{~d}$ & $2.124 \mathrm{a}$ & \\
\hline
\end{tabular}

* Interactions means or rates of $\mathrm{Cd}$ or $\mathrm{Pb}$ that have the same letter are not significantly different at $(\mathrm{P} \leq \mathbf{0 . 0 0 1})$.

Effect of $\mathrm{Cd}$ and $\mathrm{Pb}$ on $\mathrm{BCF}$ of $\mathrm{Pb}$ : From the results of Duncan's multiple range test (Table 17) it appears that $\mathrm{BCF}$ value for $\mathrm{Pb}$ reached 2.560 at the interaction between $(110 \mathrm{Cd}$ and $550 \mathrm{~Pb}) \mathrm{mg}$ $\mathrm{kg}^{-1}$, and significantly decreased from the value 3.026 at the interaction of $(550 \mathrm{~Pb}$ and zero $\mathrm{Cd})$ $\mathrm{mg} \mathrm{kg}^{-1}$, and it was significantly higher than the BCF of 3.026, the values of this study were close to Abbasi et al. (1) in their study on seedlings of Acer cappadocicum, Fraxinus excelsior and Platycladus orientalis, as it showed the significant superiority over all values of $\mathrm{BCF}$ for $\mathrm{Pb}$ at the control their values approached 3,2, and 1.6 in $\mathrm{P}$. orientalis, F. excelsior and A. cappadocicum seedlings, respectively. The BCF value in the plant depends on the type and concentration of heavy metals in the soil as well as on the plant type and the surrounding environmental conditions (25), that value of $\mathrm{BCF}(>1)$ in the plant is a good indication of phytoremediation of soils contaminated with the heavy metals $(35,39)$. Effect of $\mathbf{C d}$ and $\mathrm{Pb}$ on $\mathrm{CI}$ of $\mathrm{Pb}$ : The results of Duncan's multiple range test (Table 18) showed that the $\mathrm{CI}$ values of $\mathrm{Pb}$ increased with the increasing of $\mathrm{Cd}$ and $\mathrm{Pb}$ concentration in the soil, as for the effect of the interaction between $\mathrm{Cd}$ and $\mathrm{Pb}$, it appears that the highest $\mathrm{CI}$ value was 3.833 at the between interaction $(110 \mathrm{Cd}$ and $550 \mathrm{~Pb}$ ) $\mathrm{mg} \mathrm{kg}^{-1}$, and it was significantly superior to all CI value, it was noticed that there was no significant 
difference between the control and the $\mathrm{CI}$ of 1.006 at the interaction $(110 \mathrm{Cd}$, zero $\mathrm{Pb}) \mathrm{mg} \mathrm{kg}^{-1}$,

Table 17. Duncan's multiple-range test results for effect of $\mathrm{Cd}$ and $\mathrm{Pb}$ and their interactions in BCF of Pb.

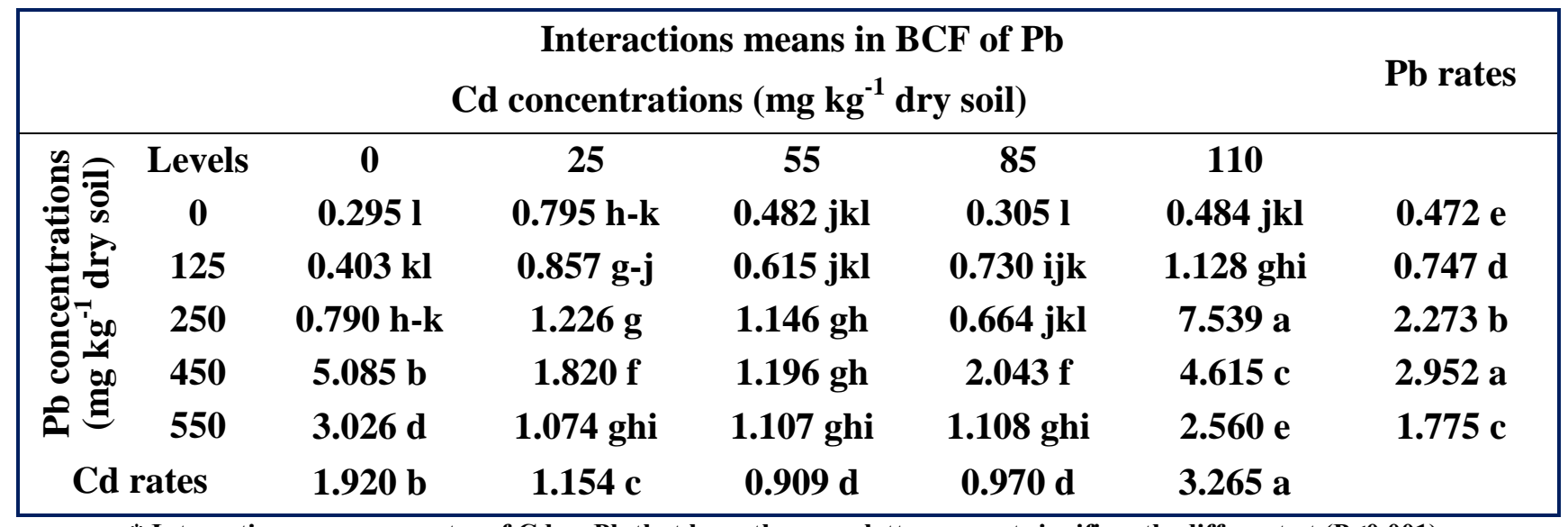

* Interactions means or rates of $\mathrm{Cd}$ or $\mathrm{Pb}$ that have the same letter are not significantly different at $(\mathrm{P} \leq \mathbf{0 . 0 0 1})$.

Table 18. Duncan's multiple-range test results for effect of $\mathrm{Cd}$ and $\mathrm{Pb}$ and their interactions in CI of Pb.

\begin{tabular}{|c|c|c|c|c|c|c|c|}
\hline & & & $\begin{array}{l}\text { Interac } \\
\text { concentra }\end{array}$ & $\begin{array}{l}\text { is means } \\
\text { is (mg kg }\end{array}$ & $\begin{array}{l}\text { I of } \mathbf{P b} \\
\text { y soil) }\end{array}$ & & $\mathrm{Pb}$ rates \\
\hline$\cong=$ & Level & $\mathbf{0}$ & 25 & 55 & 85 & 110 & \\
\hline$\stackrel{0}{\circ}$ & $\mathbf{0}$ & $1.000 \mathbf{~ i j ~}$ & 1.093 hij & $0.958 \mathbf{i j}$ & $0.880 \mathrm{j}$ & $1.006 \mathrm{ij}$ & 0.987 e \\
\hline$\stackrel{\Xi}{\Xi}$ & 125 & 1.085 hij & $1.314 \mathrm{fgh}$ & $1.154 \mathrm{hi}$ & $1.431 \mathrm{fg}$ & $1.283 \mathrm{gh}$ & $1.253 \mathrm{~d}$ \\
\hline 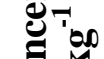 & 250 & $1.519 \mathrm{fg}$ & $1.554 \mathrm{f}$ & $1.516 \mathrm{fg}$ & $1.934 \mathrm{de}$ & $3.439 \mathrm{~b}$ & $1.992 \mathrm{c}$ \\
\hline 80 & 450 & $2.694 \mathrm{c}$ & $1.816 \mathrm{e}$ & $1.443 \mathrm{fg}$ & $2.009 \mathrm{de}$ & $2.650 \mathrm{c}$ & $2.122 b$ \\
\hline & $\mathbf{5 5 0}$ & 2.013 de & $2.111 \mathrm{~d}$ & $1.498 \mathrm{fg}$ & $1.817 \mathrm{e}$ & $3.833 \mathrm{a}$ & $2.254 \mathrm{a}$ \\
\hline Cd & cates & $1.662 \mathrm{~b}$ & $1.578 \mathrm{~b}$ & $1.314 \mathrm{c}$ & $1.614 \mathrm{~b}$ & $2.442 \mathrm{a}$ & \\
\hline
\end{tabular}

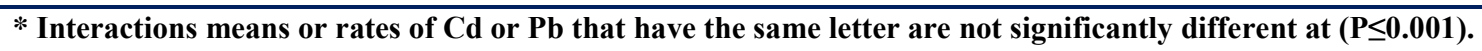

Effect of $\mathrm{Cd}$ and $\mathrm{Pb}$ on $\mathrm{TI}$ : The results of Duncan's multiple range test (Table 19) showed that the TI values decreased in seedlings with an increase in the concentration of $\mathrm{Cd}$ and $\mathrm{Pb}$ in the soil, as for the effect of the interaction between $\mathrm{Cd}$ and $\mathrm{Pb}$, it appears that the smallest value of TI was 0.370 at the interaction $(110 \mathrm{Cd}$ and 550 $\mathrm{Pb}) \mathrm{mg} \mathrm{kg}^{-1}$, and $\mathrm{TI}$ value was 0.536 at the interaction (110 Cd, zero $\mathrm{Pb}) \mathrm{mg} \mathrm{kg}^{-1}$, and the results of this study relatively outperformed the results reported by Kabir et al. (26) in their study on Leucaena leucocephala seedlings treated with

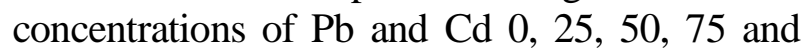
$100 \mathrm{ppm}$ each single and mixed, as they found that the TI value was 0.623 when the interaction $(100 \mathrm{Cd}$ and $100 \mathrm{~Pb}) \mathrm{mg} \mathrm{kg}^{-1}$. The reason for the decrease in TI values with increasing concentrations of $\mathrm{Cd}$ and $\mathrm{Pb}$ in the soil is due to the stress of heavy metals effect, which leads to inhibit the growth of the plant, which causes a decrease in the biomass, according to the type of plant and type and amount of toxins absorbed in the cellular tissues $(13,15)$.

CONCLUSIONS: Eucalyptus seedlings have good ability to accumulate and concentrate $\mathrm{Cd}$ in their shoot, based on TF values greater than one, as well as for BAC, BCF, and CI which confirmed the ability of seedlings to accumulate and transfer elements from soil to root and shoot, and that seedlings have a good ability to absorb and accumulate $\mathrm{Pb}$ in their roots, when increasing the concentration of $\mathrm{Pb}$ in the soil, whether alone or in the presence of $\mathrm{Cd}$, as $\mathrm{BCF}$ values for $\mathrm{Pb}$ increased than one, as well as for TF, BAC, CI and TI, which confirms the seedlings ability to resist high concentrations of $\mathrm{Pb}$. And despite the increase in $\mathrm{Cd}$ and $\mathrm{Pb}$ concentrations at critical limits in plant parts, seedlings resisted these concentrations even though their growth was negatively affected. 
And TF and BAC value greater than one showed that Eucalyptus camaldulensis Dehnh. seedlings were suitable for use in phytoextraction

Table 19. Duncan's multiple-range test results for effect of $\mathrm{Cd}$ and $\mathrm{Pb}$ and their interactions in TI. applications of soils contaminated with $\mathrm{Cd}$ and $\mathrm{Pb}$ within the phytoremediation processes.

\begin{tabular}{|c|c|c|c|c|c|c|c|}
\hline \multirow{7}{*}{ 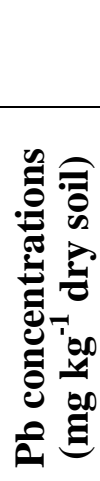 } & \multicolumn{6}{|c|}{$\begin{array}{c}\text { Interactions means in TI } \\
\text { Cd concentrations ( } \mathrm{mg} \mathrm{kg}^{-1} \text { dry soil) }\end{array}$} & \multirow[t]{2}{*}{$\mathrm{Pb}$ rates } \\
\hline & Level & $\mathbf{0}$ & 25 & 55 & 85 & 110 & \\
\hline & 0 & $1.000 \mathrm{a}$ & 0.920 a-d & 0.837 b-f & $0.796 \mathrm{~d}-\mathrm{g}$ & $0.536 \mathbf{i j}$ & 0.818 a \\
\hline & 125 & 0.941 abc & 0.848 b-e & 0.782 efg & 0.786 efg & $0.480 \mathrm{jk}$ & 0.767 b \\
\hline & 250 & 0.950 abc & $0.826 c-f$ & 0.756 e-h & 0.755 e-h & 0.455 jk & 0.749 bc \\
\hline & 450 & 0.959 ab & 0.767 e-h & 0.719 e-h & 0.646 hi & 0.423 jk & 0.703 c \\
\hline & 550 & 0.918 a-d & $0.682 \mathrm{gh}$ & 0.709 fgh & $0.519 \mathbf{j}$ & $0.370 \mathrm{k}$ & $0.640 \mathrm{~d}$ \\
\hline \multicolumn{2}{|c|}{ Cd rates } & 0.954 a & 0.809 b & 0.761 b & $0.700 \mathrm{c}$ & $0.453 \mathrm{~d}$ & \\
\hline
\end{tabular}

* Rates of $\mathrm{Cd}$ or $\mathrm{Pb}$ that have the same letter are not significantly different at $(\mathrm{P} \leq \mathbf{0 . 0 0 1})$.

\section{REFERENCES}

1. Abbasi, H., M. R. Pourmajidian, S. M. Hodjati, A. Fallah, and S. Nath. 2017. Effect of soil-applied lead on mineral contents and biomass in Acer cappadocicum, Fraxinus excelsior and Platycladus orientalis seedlings. iForest-Biogeosciences and Forestry. 10(4): 722.

2. Abdelsalam, I. M., M. Elshobary, M. M. Eladawy, and M. Nagah. 2019. Utilization of multitasking non-edible plants for phytoremediation and bioenergy source-A review. Phyton. 88(2): 69.

3. Ahmed, I. G., M. Sulaiman, A. Abdurrahman, and A. D. Abdulkarim. 2018. Phytoremediation: a preeminent alternative method for bioremoval of heavy metals from environment. J Adv Res Appl Sci Eng Technol. 10: 59-71.

4. Alkhatib, R., M. Mheidat, N. Abdo, M. Tadros, L. Al- Eitan, and K. Al- Hadid. 2019. Effect of lead on the physiological, biochemical and ultrastructural properties of Leucaena leucocephala. Plant Biology. 21(6): 1132-1139.

5. Al-Khazan, M. M., and R. M. Al-Zlabani. 2019. Toxic materials phytoremediation potential of four common trees in Saudi Arabia: A review. The Egyptian Journal of Experimental Biology (Botany). 15(1): 87-97.

6. Andrade Júnior, W.V., C.F. de Oliveira Neto, B.G.D. Santos Filho, C.B. do Amarante, E.D. Cruz, R.S. Okumura, A.V.C. Barbosa, D.J.P. de Sousa, J.S.S. Teixeira, and A.D.S. Botelho. 2019. Effect of cadmium on young plants of Virola surinamensis. AoB Plants. 11(3): plz022.

7. Ang, L. H., L. K. Tang, W. M. Ho, T. F. Hui, and G. W. Theseira. 2010. Phytoremediation of Cd and $\mathrm{Pb}$ by four tropical timber species grown on an ex-tin mine in Peninsular Malaysia. International

Journal of Environmental and Ecological Engineering. 4(2): 70-74.

8. Ashraf, F., G. Abbas, B. Murtaza, M. Amjad, M. Imran, M. A. Naeem, M. Saqib, et al. 2018. Comparative tolerance and phytostabilization potential of Conocarpus erectus and Eucalyptus camaldulensis grown in cadmium contaminated soil. Pakistan Journal of Agricultural Sciences. 55(3).

9. Bajwa, B. K. 2014. Phytoremediation of Cadmium and Lead Contaminated Soil Through Multipurpose Tree Species. M.Sc. Thesis, Dept. of Soil Sci., Coll. of Agriculture, Punjab Agricultural University, Ludhiana.

10. Cánovas, F. M. 2019. Molecular Physiology and Biotechnology of Trees. Academic Press. 89.

11. Chandra, R., and K. Hoduck. 2018. Phytoremediation and Physiological Effects of Mixed Heavy Metals on Poplar Hybrids. Heavy Metals. 183.

12. de Souza, S. C. R., S. A. L. de Andrade, L. A. de Souza, and M. A. Schiavinato. 2012. Lead tolerance and phytoremediation potential of Brazilian leguminous tree species at the seedling stage. Journal of Environmental Management. 110: 299-307.

13. Dickinson, N. M., T. Punshon, R. B. Hodkinson, and N. W. Lepp. 1994. Metal tolerance and accumulation in willows. Willow Vegetation Filters for Municipal Wastewater and Sludges, Swedish University of Agricultural Sciences, Uppsala. 121-127.

14. Dmuchowski, W., D. Gozdowski, P. Brągoszewska, A. H. Baczewska, and I. Suwara. 2014. Phytoremediation of zinc contaminated soils 
using silver birch (Betula pendula Roth). Ecological engineering. 71: 32-35.

15. Dos Santos Utmazian, M. N., G. Wieshammer, R. Vega, and W. W. Wenzel. 2007. Hydroponic screening for metal resistance and accumulation of cadmium and zinc in twenty clones of willows and poplars. Environmental Pollution. 148(1): 155-165. 16. El-Amier, Y. A., and S. M. Alghanem. 2018. Tree leaves as bioindicator of heavy metal pollution from soil and ambient air in urban environmental. Plant Archives. 18(2): 2559-2566.

17. El-Mahrouk, E. S. M., E. A. H. Eisa, M. A. Hegazi, M. E. S. Abdel-Gayed, Y. H. Dewir, M. E. El-Mahrouk, and Y. Naidoo. 2019. Phytoremediation of cadmium-, copper-, and leadcontaminated soil by Salix mucronata (Synonym Salix safsaf). HortScience. 54(7): 1249-1257.

18. Elmer, P. 1996. Analytical methods for atomic absorption spectroscopy. USA: The Perkin-Elmer Corporation. 132-142.

19. Emamverdian, A., and Y. Ding. 2017. Effects of heavy metals toxicity on plants and enhancement of plant defense mechanisms of Si-mediation Review. International Journal of Environmental and Agriculture Research. 3(4): 41-51.

20. Eun, S. O., H. Shik Youn, and Y. Lee. 2000. Lead disturbs microtubule organization in the root meristem of Zea mays. Physiologia plantarum. 110(3): 357-365.

21. Gebretsadik, H., A. Gebrekidan, and L. Demlie. 2020. Removal of heavy metals from aqueous solutions using Eucalyptus Camaldulensis: An alternate low cost adsorbent. Cogent Chemistry. 6(1): 1720892.

22. Heidari, M., and S. Sarani. 2011. Effects of lead and cadmium on seed germination, seedling growth and antioxidant enzymes activities of mustard (Sinapis arvensis L.). ARPN Journal of Agricultural and Biological Science. 6(1): 44-47.

23. Hussain, Z., M. Zubair, W. Nouman, I. Ashraf, R. Qureshi, M. F. Nawaz, and K. A. Ansari. 2018. Phytoremedial potential of Azadirachta indica A. Juss. for lead contamination under saline conditions. Pakistan Journal of Weed Science Research. 24(2).

24. Ismael, M. A., A. M. Elyamine, M. G. Moussa, M. Cai, X. Zhao, and C. Hu. 2019. Cadmium in plants: uptake, toxicity, and its interactions with selenium fertilizers. Metallomics. 11(2): 255-277.

25. Kabata-Pendias, A., and H. Pendias. 1999. Biogeochemistry of trace elements. Pwn, Warszawa. 400.

26. Kabir, M., M. Z. Iqbal, and M. Shafiq. 2018. The effects of lead and cadmium individually and in combinations on germination and seedling growth of Leucaena leucocephala (Lam.) de Wit. American Scientific Research Journal for Engineering, Technology, and Sciences (ASRJETS). 43(1): 33-43.

27. Khamis, M. H., E. M. El-Mahrook, and M. A. Abdelgawad. 2014. Phytoextraction potential of cadmium and lead contamination using Melia azedarach and Populus alba seedlings. African Journal of Biotechnology. 13(53).

28. Kinnersley, A. M. 1993. The role of phytochelates in plant growth and productivity. Plant growth regulation. 12(3): 207-218.

29. Lamb, D. T., H. Ming, M. Megharaj, and R. Naidu. 2010. Relative tolerance of a range of Australian native plant species and lettuce to copper, zinc, cadmium, and lead. Archives of environmental contamination and toxicology. 59(3): 424-432.

30. Landberg, T., and M. Greger. 1996. Differences in uptake and tolerance to heavy metals in Salix from unpolluted and polluted areas. Applied Geochemistry. 11(1-2): 175-180.

31. Li, M. S., Y. P. Luo, and Z. Y. Su. 2007. Heavy metal concentrations in soils and plant accumulation in a restored manganese mineland in Guangxi, South China. Environmental pollution. 147(1): 168-175.

32. Luo, Y. 2019. Environmental problems in the mining of metal minerals. In IOP Conference Series: Earth and Environmental Science. 384(1): 012195.

33. Lux, A., A. Šottníková, J. Opatrná, and M. Greger. 2004. Differences in structure of adventitious roots in Salix clones with contrasting characteristics of cadmium accumulation and sensitivity. Physiologia Plantarum. 120(4): 537545.

34. Malar, S., S. S. Vikram, P. J. Favas, and V. Perumal. 2016. Lead heavy metal toxicity induced changes on growth and antioxidative enzymes level in water hyacinths [Eichhornia crassipes (Mart.)]. Botanical studies. 55(1): 1-11.

35. Malik, R. N., S. Z. Husain, and I. Nazir. 2010. Heavy metal contamination and accumulation in soil and wild plant species from industrial area of Islamabad, Pakistan. Pak J Bot. 42(1): 291-301.

36. Mehrandish, R., A. Rahimian, and A. Shahriary. 2019. Heavy metals detoxification: A review of herbal compounds for chelation therapy in heavy metals toxicity. Journal of Herbmed Pharmacology. 8(2): 69-77.

37. Mizushima, M.Y.B., B.G. Ferreira, M.G.C. França, A.A. Almeida, P.A. Cortez, J.V.S. Silva, R.M. Jesus, M.N.V. Prasad, and P.A.O. Mangabeira. 2019. Ultrastructural and metabolic 
disorders induced by short- term cadmium exposure in Avicennia schaueriana plants and its excretion through leaf salt glands. Plant Biology. 21(5): 844-853.

38. Mleczek, M., P. Goliński, M. Krzesłowska, M. Gąsecka, Z. Magdziak, P. Rutkowski, S. Budzyńska, et al. 2017. Phytoextraction of potentially toxic elements by six tree species growing on hazardous mining sludge. Environmental Science and Pollution Research. 24(28): 22183-22195.

39. Nazir, A., R. N. Malik, M. Ajaib, N. Khan, and M. F. Siddiqui. 2011. Hyperaccumulators of heavy metals of industrial areas of Islamabad and Rawalpindi. Pak J Bot. 43(4): 1925-1933.

40. Nelson, D. M. 2016. Heavy Metal Accumulation in Urban Soil: A Phytoextraction Method Review. M.Sc. Thesis, Dept. of Biological Sci., Michigan Technological University.

41. Ng, C. C., A. Boyce, M. Rahman, and R. Abas. 2016. Phyto-assessment of soil heavy metal accumulation in tropical grasses. The Journal of Animal \& Plant Sciences. 26(3): 686-696.

42. Nikolić, N., L. Zorić, I. Cvetković, S. Pajević, M. Borišev, S. Orlović, and A. Pilipović. 2017. Assessment of cadmium tolerance and phytoextraction ability in young Populus deltoides L. and Populus xeuramericana plants through morpho-anatomical and physiological responses to growth in cadmium enriched soil. iForestBiogeosciences and Forestry. 10(3): 635.

43. Nofal, E. S., S. M. Shahin, A. M. El-Tarawy, and S. H. M. Omar. 2017. Studies on tolerance of some ornamental plants to soil pollution with some combinations of heavy metals. II. Butterfly tree (Bauhinia purpurea L.). Middle East Journal of Agriculture. 6(3): 828-834.

44. Påhlsson, A. M. B. 1989. Toxicity of heavy metals $(\mathrm{Zn}, \mathrm{Cu}, \mathrm{Cd}, \mathrm{Pb})$ to vascular plants. Water, Air, and Soil Pollution. 47(3-4): 287-319.

45. Pajević, S., M. Borišev, N. Nikolić, D. D. Arsenov, S. Orlović, and M. Župunski. 2016. Phytoextraction of heavy metals by fast-growing trees: a review. In Phytoremediation (Springer, Cham). 29-64.

46. Pulford, I. D., C. Watson, and S. D. McGregor. 2001. Uptake of chromium by trees: prospects for phytoremediation. Environmental Geochemistry and Health. 23(3): 307-311.

47. Qureshi, M. I., M. Z. Abdin, S. Qadir, and M. Iqbal. 2007. Lead-induced oxidative stress and metabolic alterations in Cassia angustifolia Vahl. Biologia Plantarum. 51(1): 121-128.
48. Rai, P. K., S. S. Lee, M. Zhang, Y. F. Tsang, and K. H. Kim. 2019. Heavy metals in food crops: Health risks, fate, mechanisms, and management. Environment International. 125: 365-385.

49. Rasheed, F., Z. Zafar, Z. A. Waseem, M. Rafay, M. Abdullah, M. M. A. Salam, M. Mohsin, and W. R. Khan. 2020. Phytoaccumulation of Zn, $\mathrm{Pb}$, and $\mathrm{Cd}$ in Conocarpus lancifolius irrigated with wastewater: does physiological response influence heavy metal uptake? International Journal of Phytoremediation. 22(3): 287-294.

50. Saleem, M.H., S. Ali, M. Rehman, M. Hasanuzzaman, M. Rizwan, S. Irshad, F. Shafiq, et al. 2020. Jute: A Potential Candidate for Phytoremediation of Metals-A Review. Plants. 9(2): 258.

51. Sauerbeck, D. $1983 . \quad$ Welche Schwermetallgehalte in Pflanzen dürfen nicht überschritten werden, um Wachstumsbeeinträchtigungen $\mathrm{zu}$ vermeiden? Landwirtsch Forsch Sonderh. 39: 108-129.

52. Shah, F. R., N. Ahmad, K. R. Masood, D. M. Zahid, and M. Zubair. 2011. Response of Eucalyptus camaldulensis to exogenous application of cadmium and chromium. Pak. J. Bot. 43(1): 181189.

53. Shanker, A. K., C. Cervantes, H. Loza-Tavera, and S. Avudainayagam. 2005. Chromium toxicity in plants. Environment international. 31(5): 739753.

54. Sharma, P., and R. S. Dubey. 2005. Lead toxicity in plants. Brazilian journal of plant physiology. 17(1): 35-52.

55. Svetková, K., and A. Fargašová. 2007. Phytotoxicity of washing wastewaters from a cutlery production line. Bulletin of environmental contamination and toxicology. 79(1): 109-113.

56. Turan, M., and A. Esringu. 2007. Phytoremediation based on canola (Brassica napus L.) and Indian mustard (Brassica juncea L.) planted on spiked soil by aliquot amount of $\mathrm{Cd}, \mathrm{Cu}, \mathrm{Pb}$, and Zn. Plant Soil and Environment. 53(1): 7.

57. Vardhan, K. H., P. S. Kumar, and R. C. Panda. 2019. A review on heavy metal pollution, toxicity and remedial measures: Current trends and future perspectives. Journal of Molecular Liquids. 290: 111197.

58. Xu, X., B. Yang, G. Qin, H. Wang, Y. Zhu, K. Zhang, and H. Yang. 2019. Growth, accumulation, and antioxidative responses of two Salix genotypes exposed to cadmium and lead in hydroponic culture. Environmental Science and Pollution Research. 26(19): 19770-19784. 